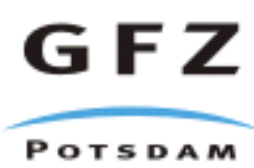

Originally published as:

Lindeque, A. S., Ryberg, T., Stankiewicz, J., Weber, M. H., de Witt, M. J. (2007): Deep Crustal Seismic Reflection Experiment Across the Sothern Karoo Basin, South Africa. South African Journal of Geology, 110, 2-3, 419-438

DOI: 10.2113/gssajg.110.2-3.419 


\title{
Deep Crustal Seismic Reflection Experiment Across the Southern Karoo Basin, South Africa
}

\author{
Ansa S. Lindeque \\ CGS - Council for Geoscience, Western Cape, P.O. Box 572, Bellville 7535, Cape Town, South Africa \\ GFZ - GeoForschungsZentrum Potsdam, Telegrafenberg 14473, Potsdam, Germany \\ AEON - Africa Earth Observatory Network and Department of Geological Sciences, \\ University of Cape Town, Rondebosch 7701, South Africa \\ e-mail: ansali@gfz-potsdam.de or alindeque@geoscience.org.za \\ Trond Ryberg and Jacek Stankiewicz \\ GFZ - GeoForschungsZentrum Potsdam, Telegrafenberg 14473, Potsdam, Germany \\ e-mail: trond@gfz-potsdam.de; jacek@gfz-potsdam.de \\ Michael H. Weber \\ GFZ - GeoForschungsZentrum Potsdam, Telegrafenberg 14473, Potsdam, Germany \\ University of Potsdam, Karl Liebknecht Strasse 24, 14476 Potsdam, Germany \\ e-mail: mhw@gfz-potsdam.de \\ Maarten J. de Wit \\ GeoForschungsZentrum Potsdam, Telegrafenberg 14473, Potsdam, Germany \\ AEON - Africa Earth Observatory Network and Department of Geological Sciences, \\ University of Cape Town, Rondebosch 7701, South Africa \\ e-mail:maarten.dewit@uct.ac.za
}

(c) 2007 September Geological Society of South Africa

\begin{abstract}
A controlled source Near Vertical Reflection (NVR) Seismic experiment along a $\sim 100 \mathrm{~km}$ profile yields the first high quality seismic image of the crust and Moho across the southern Karoo Basin in South Africa. The highly reflective crust comprises upper, middle and lower layers. In the upper crust, folded and gently south-dipping continuous reflectors up to the Escarpment, represent the bedding of the Karoo and Cape Supergroups respectively. Décollement structures occur locally along carbonaceous shales of the Whitehill Formation. A well-defined mid-crustal layer that hosts the Beattie Magnetic Anomaly (BMA), occurs below a seismically imaged unconformity. The mid-crustal layer is $\sim 20 \mathrm{~km}$ thick in the vicinity of the BMA and is likely to be a subsurface continuation of the 1.0 to $2.0 \mathrm{Ga}$ granitoid gneisses of the Bushmanland sub-province in the 1.2 to $1.0 \mathrm{Ga}$ Namaqua-Natal Orogenic Belt. The internal seismic fabric of this layer is interpreted as a tectonic fabric dipping to the north. The probable source of the BMA appears at 7 to $15 \mathrm{~km}$ depth, as a narrow feature in a $\sim 10 \mathrm{~km}$ wide tectonically complex zone confined to the upper midcrust. The underlying lower crustal layer is wedge-shaped: $\sim 24 \mathrm{~km}$ thick in the north and decreasing to $\sim 12 \mathrm{~km}$ thick beneath the Cape Fold Belt. This lower crustal layer may represent granulite-gneisses of the Namaqua sub-province. The internal seismic fabric in the upper part of this layer dips both to the north and south, but a north-dipping fabric dominates the lower part. A clearly imaged undulating Moho occurs at a depth of $\sim 43 \mathrm{~km}$ in the north, with a nick point at $\sim 42 \mathrm{~km}$ depth, $\sim 35 \mathrm{~km}$ along the profile, and then deepens to $\sim 45 \mathrm{~km}$ in the south beneath the tectonic front of the Cape Fold Belt. A possible $\sim 1$ to $2 \mathrm{~km}$ thick lowermost crustal layer of high seismic reflectivity, overlies the Moho and may represent underplated mafic material. The reflectivity seen in this NVR seismic image bears similarities to seismic transects across the coeval Mesoproterozoic Grenville orogen in Canada.
\end{abstract}

\section{Introduction}

The seismic reflection profile described in this paper, is part of the Inkaba yeAfrica, Agulhas-Karoo OnshoreOffshore Geoscience Transect (de Wit and Horsfield, 2006). The Agulhas-Karoo Transect consists of a 600 $\mathrm{km}$ onland section across the Kaapvaal Craton, Karoo Basin, Cape Fold Belt and Kango Inlier, and a $\sim 400 \mathrm{~km}$ offshore section over the southern continental margin of Africa, Agulhas Fracture Zone and the Agulhas Plateau. Onland datasets comprise $\sim 240 \mathrm{~km}$ of wide-angle seismic refraction data (Stankiewicz et al. 2007), 600 $\mathrm{km}$ of magnetotelluric data (Weckmann et al. 2007a; b) and $\sim 100 \mathrm{~km}$ of Near Vertical Reflection (NVR) seismic data, all acquired between 2003 and 2006 (Figure 1). The offshore extension of the transect was completed in 2005, and Parsiegla et al. (2007) report on the results. The Agulhas-Karoo transect crosses distinctive deep crustal features of South Africa such as the Beattie Magnetic Anomaly (BMA), the Southern Cape Conductive Belt (SCCB), the Namaqua-Natal Orogenic Belt (NNOB) and the sheared continental margin adjacent to the Agulhas fracture zone.

The NVR seismic experiment was conducted between October-December 2005, along a section that 


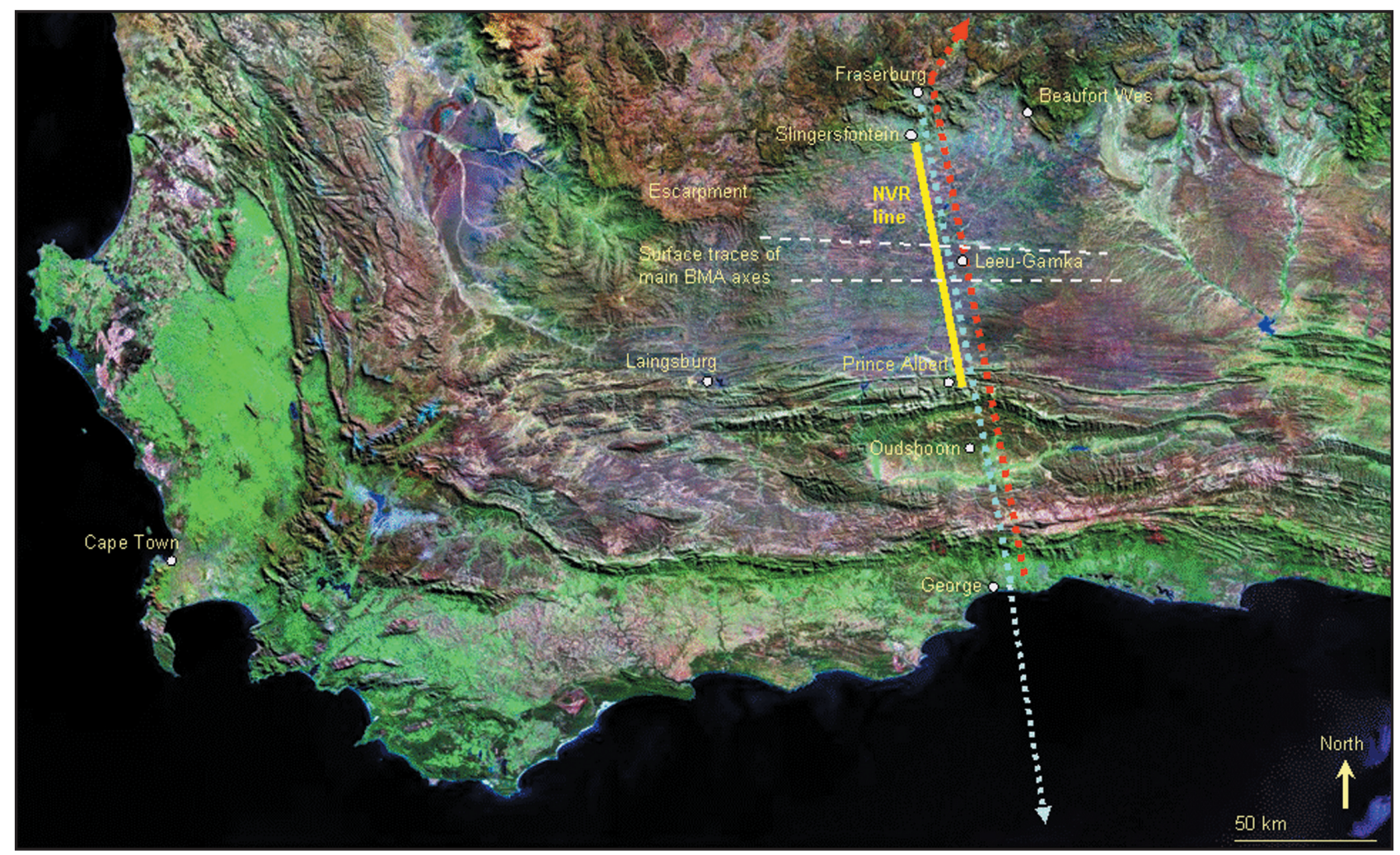

Figure 1. Satellite image of southwest South Africa showing the location map of the Agulhas-Karoo Geoscience Transect and surrounding towns. The different onshore-offshore experiments of the Agulhas-Karoo Transect are: yellow = Near Vertical Reflection (NVR) seismic line; dashed; light blue $=$ Wide Angle Reflection Seismics (WRR) onshore-offhore line; red = Magnetotellurics profile. Surface traces of the main axes of the Beattie Magnetic Anomaly are indicated by the white dashed lines. (Image source: https://zulu.ssc.nasa.gov/)

runs from Prince Albert and past Leeu Gamka to Slingersfontein, (yellow line, Figure 1) near the centre of the Agulhas-Karoo transect. The objectives of the experiment were to investigate the seismic character of the crust; to locate the possible source of the BMA; and to generate a seismic reflection image of the crust. For optimal imaging, the north-south NVR seismic line traverses the east-west strike of the BMA and regional geology more or less perpendicularly. More than 30 years ago, a seismic section was completed near Beaufort West by the Southern Oil Exploration Corporation (Fatti and Du Toit, 1970), but the data were of poor quality and only penetrated into the uppermost crust. The NVR dataset that we report on here, provides excellent images of the crust and contributes new understanding of the tectonic evolution of the Karoo basin and its underlying Mesoproterozoic crust.

\section{Geology and Tectonic Setting}

Figure 2a shows the geological setting of the NVR seismic line. In the south near Prince Albert, the tectonic front of the $\sim 250$ Ma Cape Fold Belt consists of structurally complex east to west striking northwardverging overturned folds. North from here, the sedimentary rocks of the Mesozoic Karoo Basin are more gently folded and become near horizontal towards the Escarpment at the northern end of the seismic line. Here, the Karoo Basin is intruded by Jurassic Karoo dolerites ( $182 \mathrm{Ma})$. The underlying NNOB basement has been encountered in several deep drill holes through the Karoo Basin (Eglington and Armstrong, 2003). Table 1 summarises the regional stratigraphy along the NVR transect that is briefly described below in descending age.

\section{The Karoo Supergroup}

The $\sim 700000 \mathrm{~km}^{2}$ Karoo Basin is a foreland basin to the Cape Fold Belt that contains up to $12 \mathrm{~km}$ of Late Carboniferous to Mid Jurassic sedimentary and argillaceous shale, siltstone and sandstone strata (Broquet 1992; Cole, 1992; Cloetingh et al. 1992; Catuneanu et al. 1998). Cole (1992) and Cloetingh et al. (1992, Table 2) report a thickness of $\sim 11905 \mathrm{~m}$ for the Karoo Supergroup sediments in the Eastern Cape Province and a thickness of $\sim 4610 \mathrm{~m}$ in the South Western Cape Province near the location of the NVR seismic line. The Karoo Supergroup is subdivided in the Beaufort, Ecca and Dwyka Groups (Table 1). The middle sequence of upper Ecca comprises turbidites that grade upward into coarse fluvial sandstones of the Beaufort Group (Abrahamskraal Formation) and are underlain by the deeper water carbonaceous shales ( 35 to $44 \mathrm{~m}$ thick Whitehill and $\sim 180 \mathrm{~m}$ thick Prince Albert Formations) of the Ecca Group. The Ecca is abruptly underlain by 600-700 $\mathrm{m}$ thick and dense diamictites of the Permo-Carboniferous Dwyka tillites (e.g., Visser 1987; Visser et al. 1987; Johnson et al. 1997). In the south of the profile, Karoo strata are tightly folded in 
Table 1. Stratigraphy along the NVR transect and basement. Only the prominent unconformity between the Cape Supergroup and Namaqua-Natal Orogenic Belt (NNOB) and a local decollement, seen in the seismic image are indicated. Pale grey $=$ no outcrop along the NVR seismic line e.g., Cape Supergroup and NNOB. Stratigraphy taken from the 1:250000 Geological series map sheets 3220, 3222, 3320, 3322 and The Stratigraphic Table of South Africa, compiled by the Council for Geoscience.

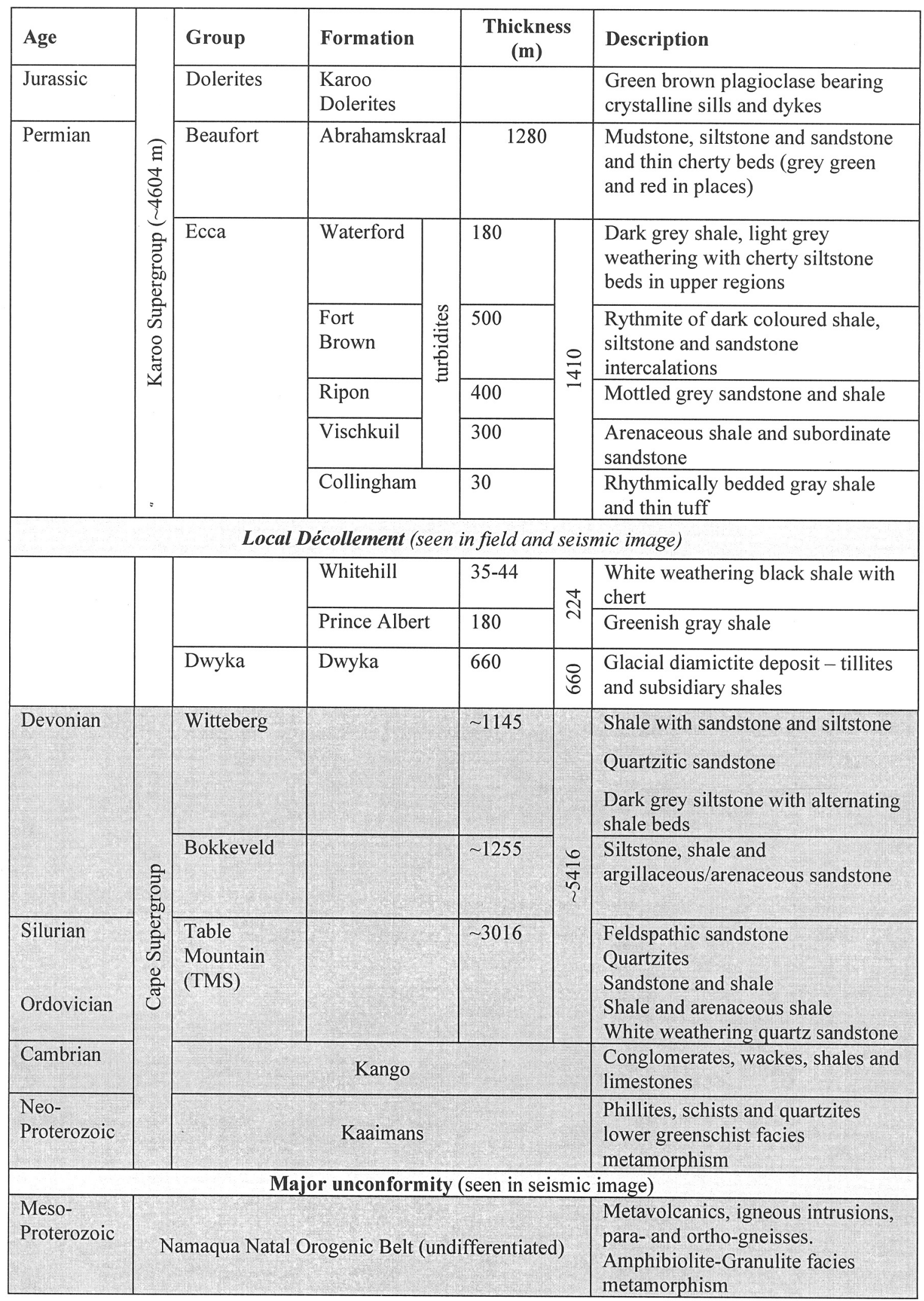




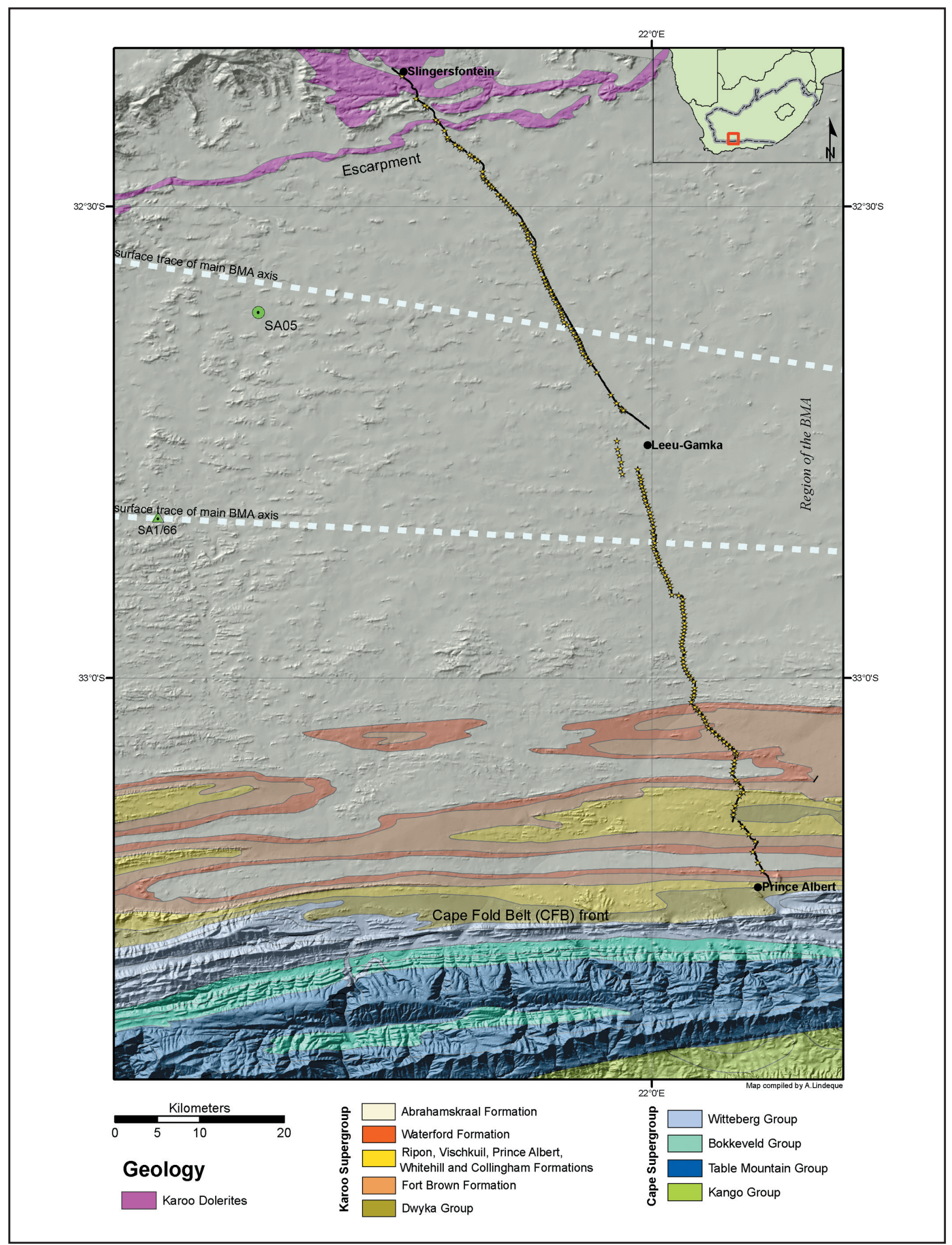

Figure 2. (a) Geology and $20 \mathrm{~m}$ digital elevation model with the location of the north-south NVR seismic profile: sources = yellow stars; receivers = black dots. In the south, the tectonic front of the Cape Fold Belt is a structurally complex zone of east to west striking overturned folds. The adjacent Karoo Basin comprises tightly spaced parallel east-west striking regional open folds up to the north end of the profile at the Escarpment, where the Karoo Supergroup is intruded by the Jurassic Karoo dolerites and sills. circle = receiver function station SA05 (Harvey et al., 2001); triangle = borehole (Cole and McLachlan 1994; boreholes from Eglington and Armstrong 2003 not shown on map but are $\sim 50 \mathrm{~km}$ to either side of the line); dashed lines = surface projection of the main BMA axes. 
north-verging folds that grade into gentler dips further northwards. Field evidence shows that the Karoo sediments are locally dislocated along a décollement in the Whitehill Formation (e.g., Figure 34, p.44 in Knütter 1994, and personal observations). Directly below the Escarpment, the Karoo sequence is flat-lying and intruded by Jurassic dolerite sills and dykes (Chevallier and Woodford, 1999). Johnson et al. (1997) and Catuneanu et al. (1998) provide more detailed accounts of the stratigraphy, sedimentology and palaeoenvironment.

\section{Cape Supergroup and Cape Fold Belt}

The Cape Supergroup (CSG) consists of $\sim 3 \mathrm{~km}$ thick lower Neoproterozoic Cambrian metasediments that crop out in local basal rift sequences (e.g., Kango Inlier, Barnett et al. 1997), overlain by $\sim 8 \mathrm{~km}$ Ordovician to Carboniferous clastic sediments and quartzites (Hälbich, 1983, 1993; Tankard et al. 1982; Broquet, 1992; Catuneanu et al. 1998). The lower Table Mountain Sandstone Group (TMS) comprises $\sim 3 \mathrm{~km}$ thick bedded, dense and hard quartzites (Broquet, 1992 and references therein). The CSG, together with the overlying Dwyka to lower Beaufort Group was deformed at $\sim 250 \mathrm{Ma}$ by Cape Fold Belt (CFB) tectonism (Hälbich 1993; Hälbich and Swart, 1983). The CFB comprises complex extensional and compressional structures with thrusts and asymmetric folds verging northward. At surface the folding is complex, with steeply dipping to overturned bedding along northern fold limbs. Dominant CFB thrusts are south-dipping and may coalesce into a common décollement (Hälbich, 1983, 1993; Newton 1992; Paton et al. 2006). The NVR seismic section extends to the northern-most surface expression of the CFB tectonic front (Figure 2a).

\section{Namaqua-Natal Orogenic Belt (NNOB)}

The NNOB basement, in tectonic contact with the Archean Kaapvaal craton to the north, runs east to west across South Africa and crops out on the west coast in Namaqualand and along the east coast in KwaZulu-Natal (Figure 2b). In the centre it is covered by the Karoo and Cape Supergroups. The NNOB tectonic provinces shown in Figure $2 \mathrm{~b}$ are briefly described below:

In the west, the Namaqua Province comprises highgrade metamorphic rocks of the Bushmanland, Richtersveld and Namaqua sub-provinces or terranes. These three terranes amalgamated with the Archean Kaapvaal Craton during late Mesoproterozoic orogenesis ( $\sim 950$ to $1400 \mathrm{Ma}$ ) to form the NNOB (Robb et al. 1999; Eglington and Armstrong, 2003; Raith et al. 2003; Dewey et al. 2006; Eglington, 2006 and references therein). Metamorphism across all terranes peaked between $\sim 1.02$ to $\sim 1.04 \mathrm{Ga}$ (Eglinton, 2006). Geochronology in the $\sim 2.0$ Ga Richtersveld terrane reveals low- to medium-pressure amphibolite-granulite facies granitic and mafic ortho-gneisses, locally in tectonic contact with small remnants of lower grade Palaeoproterozoic paragneisses (Robb et al. 1999). The younger Namaqua terrane comprises high-grade (low-P granulite facies) granitic ortho-gneisses. The tectonically overlying Bushmanland rocks contain both ortho- and paragneisses at slightly lower metamorphic grades (Raith et al. 2003). The paragneisses of the Bushmanland terrane also contain large stratabound base-metal (copper, zinc and lead sulphides) ore deposits in regional open upright folds (Thomas et al. 1994). Along the west coast, the high-grade metamorphism was locally overprinted during Neoproterozoic (Pan-African, 0.5 to $0.7 \mathrm{Ga})$ tectonism at low metamorphic grades (e.g., Tankard et al. 1982; Frimmel and Frank 1998).
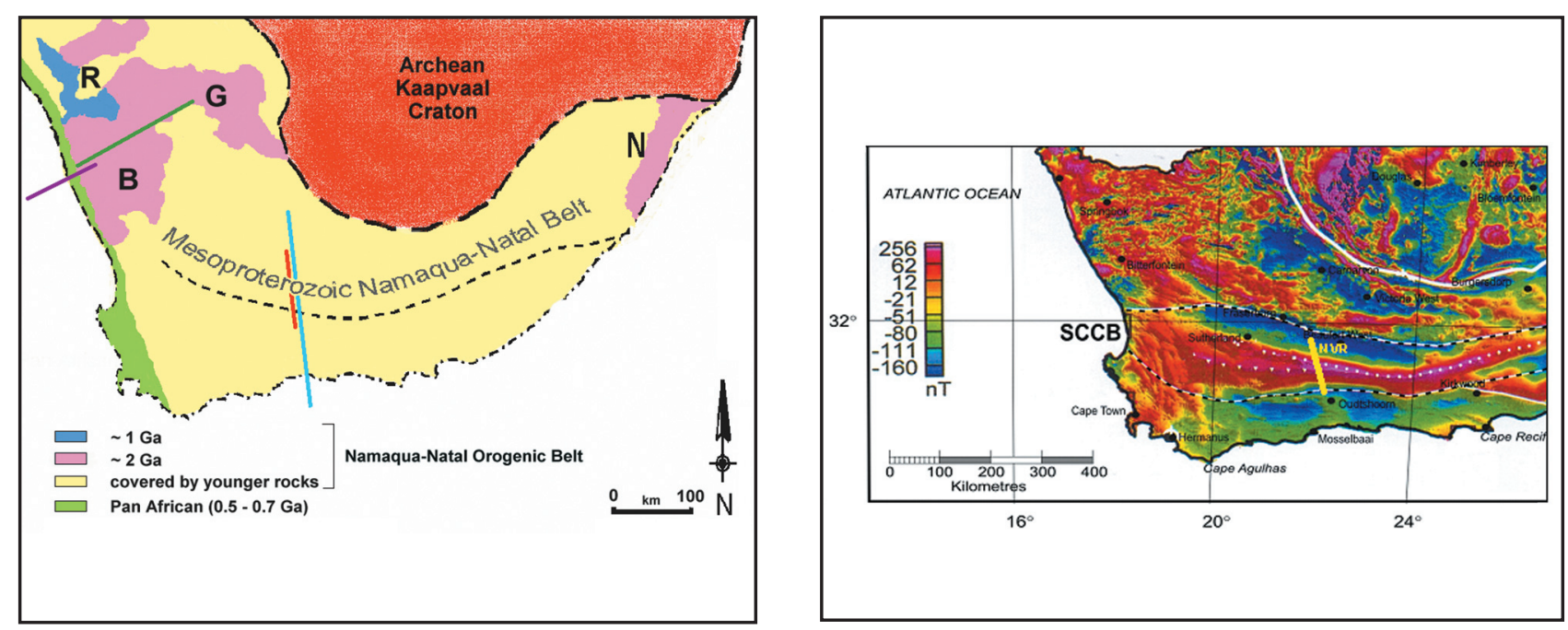

Figure 2. continued (B) Simplified map of the Namaqua-Natal Orogenic Belt (NNOB) flanking the Kaapvaal Craton. The Namaqua province (west coast) is divided into the Richtersveld (R), Gordonia (G) and Bushmanland (B) sub-provinces. $\mathrm{N}=\mathrm{Natal}$ province (east coast). The projected NNOB under the Karoo Basin is shown in yellow. The southernmost extremity of the NNOB (Hälbich 1993 model) indicated with the black dashed line. Seismic refraction lines: green = Green and Durrheim 1990; purple = Mahanyele et al. 2004 ; blue = Stankiewicz et al. 2007; red = NVR seismic line, this work. (C) Regional Aeromagnetic map of the Western Cape in South Africa. White dots = Beattie Magnetic Anomaly (BMA) axes; black and white dashed line = Southern Cape Conductive Belt $($ SCCB); white line = estimated edge of the Kaapvaal craton. The NVR seismic line is shown in yellow. Map modified after Barrett (1993). 
The structural history of the NNOB includes regional ductile deformation with refolded recumbent folds, thrusting and listric shear zones that produced tectonic wedges with strong shallow to steep dipping tectonic fabrics, and regionally extensional shear zones that separate the Namaqua terrane from the overlying Bushmanland terrane. Along the west coast, a $\sim 300 \mathrm{~km}$ long seismic refraction profile across the NNOB (Figure 2b) reports that the lower crust comprises intermediate velocity rocks $(6.2$ to $6.9 \mathrm{~km} / \mathrm{s})$ and the Moho occurs at $\sim 42 \mathrm{~km}$ (Green and Durrheim, 1990). Work on another profile in the same region by GFZ/BGR/CGS is ongoing, and will determine the Moho and seismic velocity tomography model from an onshore/offshore survey (Mahanyele et al. 2004, line location indicated in Figure 2b).

In KwaZulu-Natal, the eastern extremity of the NNOB comprises a number of smaller tectonic terranes of high-grade amphibolite-granulite facies gneisses with occasional charnockites, separated by subvertical ductile shear zones (Jacobs et al., 1993; Jacobs and Thomas, 1994; Eglington, 2006; McCourt et al. 2006). Distinct magnetic anomalies define many of the terrane boundaries (De Beer and Meyer, 1984; Jacobs et al. 1993). The central sector of the NNOB in the vicinity of the seismic profile is mostly covered by younger rocks of the Karoo Basin. A number of deep drill holes penetrated the granitic basement, and petrology and geochronology on core samples confirm that this basement is part of the NNOB (Eglington and Armstrong, 2003).

In Gondwana reconstructions, it has been suggested that the NNOB continues into Antarctica and forms part of a larger Grenville-age mobile belt that was active during the formation of the Mesoproterozoic supercontinent Rodinia (e.g., Groenewald et al. 1991; Hoffmann, 1991; 1999; Moores, 1991; Jacobs et al. 1993; Jokat et al. 2003; Torsvik, 2003).

\section{The Beattie Magnetic Anomaly}

Aeromagnetic surveys display a distinct set of east-west trending magnetic anomalies, confined to the basement beneath the Karoo Basin cover of southernmost Africa, of which the Beattie Magnetic Anomaly (BMA) is the largest (Figure 2c). The surface expression of the distinctive BMA runs east-west across South Africa $\sim 40$ $\mathrm{km}$ south of the Escarpment and $\sim 60 \mathrm{~km}$ north of the CFB front (Figure 2a). The BMA was first reported by Beattie (1909). From aeromagnetic magnetic maps the BMA spatially coincides with a 100 to $200 \mathrm{~km}$ wide electrically conductive zone known as the Southern Cape Conductivity Belt (SCCB) (Gough et al. 1973; Pitts et al. 1992). The magnitude of the BMA ranges between 200 and 500 nT (Figure 2c), ranking it as one of the largest continental crustal anomalies in the world.

De Beer and Meyer (1983; 1984) used geoelectrical and gravitational data to infer that the BMA marks the southern edge of the NNOB. Along strike, the BMA does not extend beyond the continental slope and is thus, confined to continental crust (Du Plessis and Simpson, 1974). Collectively, these authors interpreted the causative bodies of the BMA and similar adjacent smaller anomalies to lie at 0.6 to $4 \mathrm{~km}$ depths, and related these to the CFB and/or Karoo dolerite sills. Subsequently, De Beer and Gough (1980) postulated the BMA source at 25 to $38 \mathrm{~km}$ depth from Curie isotherm calculations and did not confirm a direct link between the BMA and SCCB, as previously suggested by De Beer et al. (1974). De Beer and Gough (1980) suggested that the source of the SCCB could represent partially serpentinised paleo-oceanic lithosphere at depths between 46 and $52 \mathrm{~km}$, well below the inferred BMA source region.

In subsequent interpretations of Pitts and Maher (1991), the BMA is situated in a zone of higher crustal density than adjacent zones. From gravity and magnetic data, Pitts et al. (1992) modelled the BMA source as a $30 \mathrm{~km}$ wide by $20 \mathrm{~km}$ thick south-dipping slab, with a density of $\sim 2.87 \mathrm{~g} / \mathrm{cm}^{3}$, buried more than $7 \mathrm{~km}$ below the surface. Seismic receiver functions studies above the BMA (Harvey et al. 2001) identified two crustal discontinuities at depths of 7 to $11 \mathrm{~km}$ and 17 to $19 \mathrm{~km}$, which they interpreted as the upper and lower bounds of the BMA source. For the purpose of this work it should be noted that although the BMA has been interpreted in various ways, the most accepted working model based on integrating all available geophysical data up to 1993 , is that the BMA source represents a series of south-dipping, 15 to $20 \%$ serpentinised maficultramafic (e.g., ophiolitic) slabs that delineate a fundamental tectonic boundary, interpreted as a Proterozoic paleosuture zone between NNOB terranes to the north and a younger Pan-African belt to the south (e.g., De Beer et al. 1982; Hälbich, 1983; 1993, Pitts et al. 1992). Further comprehensive details of the BMA are discussed in Weckmann et al. (2007a; b).

Like the NNOB, the BMA is often used in Gondwana reconstructions as a continental-scale magnetic marker between Africa and Antarctica, linked with its Sverdrupfjella-Kirvanveggen Anomaly (SKA) counterpart (e.g., König and Jokat, 2006 and references therein). The SKA has a strike length $>600 \mathrm{~km}$ and amplitude between 100 to $900 \mathrm{nT}$, similar to the BMA. If this link between the BMA and SKA is true, then both anomalies by implication belong to a larger 1.1 Ga Namaqua-NatalMaud Belt (Jokat et al. 2003). The large scale BMA-SKA and NNOB of southern Gondwana are extrapolated to be part of the Grenville-age belt in the Rodinia supercontinent (Groenewald et al. 1991; Jokat et al. 2003 and references therein).

\section{Tectonic model}

The most comprehensive tectonic model for the evolution of the margin of southernmost South Africa was compiled by Hälbich (1993). The segment that coincides with the NVR profile is illustrated Figure 3. In this simplified crustal section, the upper, middle and lower crustal regions are separated and defined by a 


\section{Simplified section from Hälbich 1993}

S

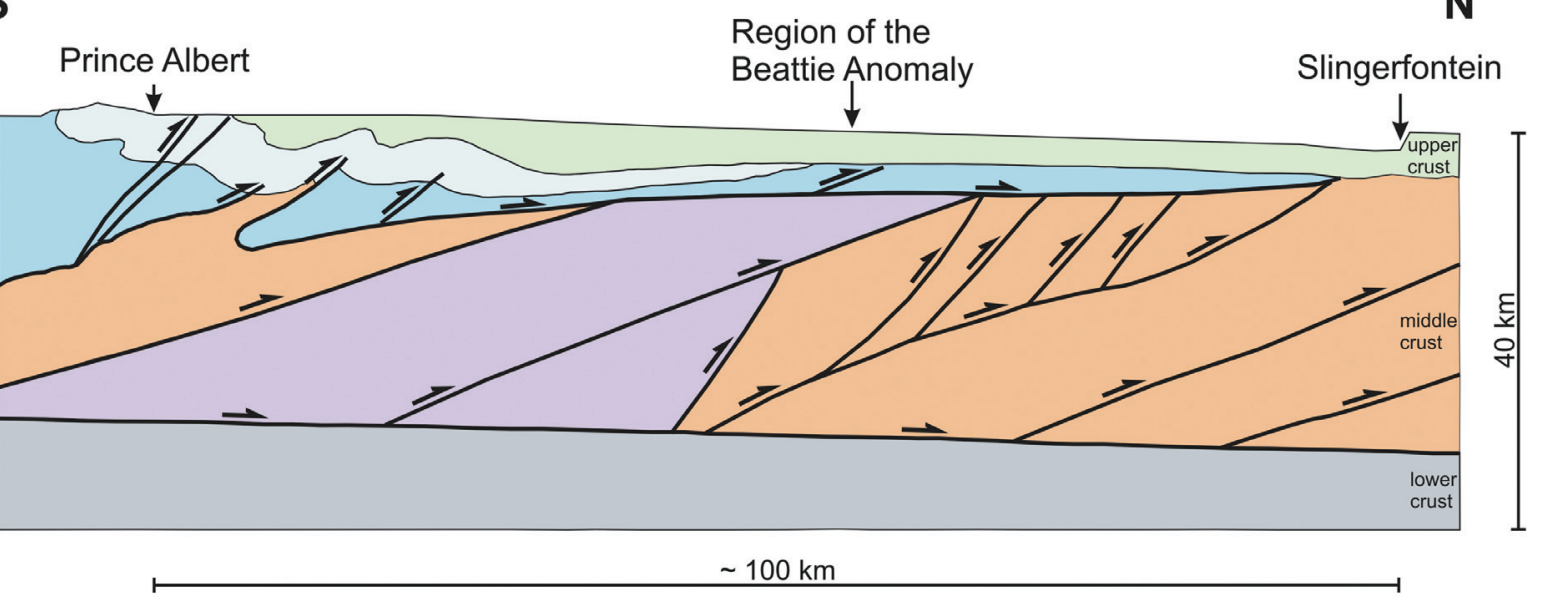

Karoo Supergroup - sediments $(0.2-0.3 \mathrm{Ga})$

Cape Supergroup - meta-sediments $(0.3-0.5 \mathrm{Ga})$

Kango Group - meta-sediments $(0.6-0.9 \mathrm{Ga})$

Namaqua Granitic Crust (1.0-1.4 Ga)

Namaqua Oceanic Crust $(1.2-1.6 \mathrm{Ga})$

Lower Continental Crust $(>1.6 \mathrm{Ga})$

Figure 3. Simplified Tectonic model across the study area, after Hälbich (1993) showing the upper and middle crustal regions that are cut by a series of southward dipping low-angle thrusts. Thrust planes in the upper crust (e.g., Cape Fold Belt-Karoo Basin) have the same north-directed tectonic vergence as those in the underlying Natal-Namaqua crystalline basement (arrows). An interpreted master thrust between the mid- and lower crust dips shallow to the north.

series of south-dipping low-angle thrusts (Figure 3). The structures in the upper crust (i.e. in the Cape Fold Belt-Karoo Basin sediments) have the same northdirected tectonic vergence as those in the underlying Natal-Namaqua crystalline basement. There is an interpreted mid-crust ophiolite wedge (e.g., a fossil subduction zone) in the region of the BMA associated with south-dipping thrust faults.

\section{Data Acquisition}

For the NVR seismic experiment, 182 boreholes at a $500 \mathrm{~m}$ nominal spacing were drilled to depth of $\sim 12 \mathrm{~m}$ and charged with $\sim 15 \mathrm{~kg}$ of explosives. An $18 \mathrm{~km}$ spread of 180 geophones spaced at $100 \mathrm{~m}$ intervals recorded the vertical component of the wave field. The main data acquisition parameters are summarised in Table 2, and locations of sources and receivers are shown on the geological map (Figure 2a). A standard roll-along technique was used daily, to move the $3.6 \mathrm{~km}$ tail-end of the $18 \mathrm{~km}$ spread to the front of the line in the north, so that it became an asymmetric split-spread geometry as the day's shot production rolled along the line. Seismic stations were synchronised by built-in GPS receivers and special GPS synchronised equipment was used to determine the shot time precisely. Through this simultaneous station and shot synchronisation, the shot instant is known to an accuracy of $\sim 1 \mathrm{~ms}$. Examples of drilling, terrain and instruments are illustrated in
Table 2. Data acquisition parameters.

\begin{tabular}{|c|c|}
\hline \multicolumn{2}{|l|}{ Source } \\
\hline Source type & $\begin{array}{l}\text { Gel explosives in borehole, with } \\
9 \mathrm{~m} \text { of rock chip stemming/tamping }\end{array}$ \\
\hline Nominal spacing & $500 \mathrm{~m}$ \\
\hline Depth & $12 \mathrm{~m}$ \\
\hline Charge & $12-15 \mathrm{~kg}$ \\
\hline Borehole diameter & $85 \mathrm{~mm}$ \\
\hline Configuration & 8 shots per $18 \mathrm{~km}$ array \\
\hline Number of shots & 182 \\
\hline \multicolumn{2}{|l|}{ Receiver } \\
\hline Geophone type & Sensor PE-6/B4 4,5Hz \\
\hline Geophone spacing & $100 \mathrm{~m} / 180$ per spread \\
\hline Geophones per receiver & \\
\hline location & 60 geophones in one string \\
\hline $\begin{array}{l}\text { Number of receiver } \\
\text { locations }\end{array}$ & 1004 in total along $100 \mathrm{~km}$ profile \\
\hline Component(s) recorded & vertical component \\
\hline Spread / Array length & $18 \mathrm{~km}$ \\
\hline Technique & $\begin{array}{l}\text { Daily "roll-along" of } 3.6 \mathrm{~km} \text { i.e. } \\
\text { asymmetric split-spread geometry }\end{array}$ \\
\hline \multicolumn{2}{|l|}{ Recording } \\
\hline Recorder type & Earth Data Logger PR6-24 \\
\hline Recording period & $17.11 .2005-11.12 .2005$ \\
\hline Profile length & $\sim 100 \mathrm{~km}$ in a N-S direction \\
\hline Number of Recorders & 60 per $18 \mathrm{~km}$ spread \\
\hline Spacing & $300 \mathrm{~m}$ \\
\hline Maximum offset recorded & $16 \mathrm{~km}$ \\
\hline Sample rate & $5 \mathrm{~ms}$ \\
\hline Trace length & $\begin{array}{l}\text { Continuous recording } \\
\text { Cut out } 20 \mathrm{~s} \text { for processing }\end{array}$ \\
\hline Maximum fold coverage & $\sim 20$ traces per CMP gather \\
\hline
\end{tabular}



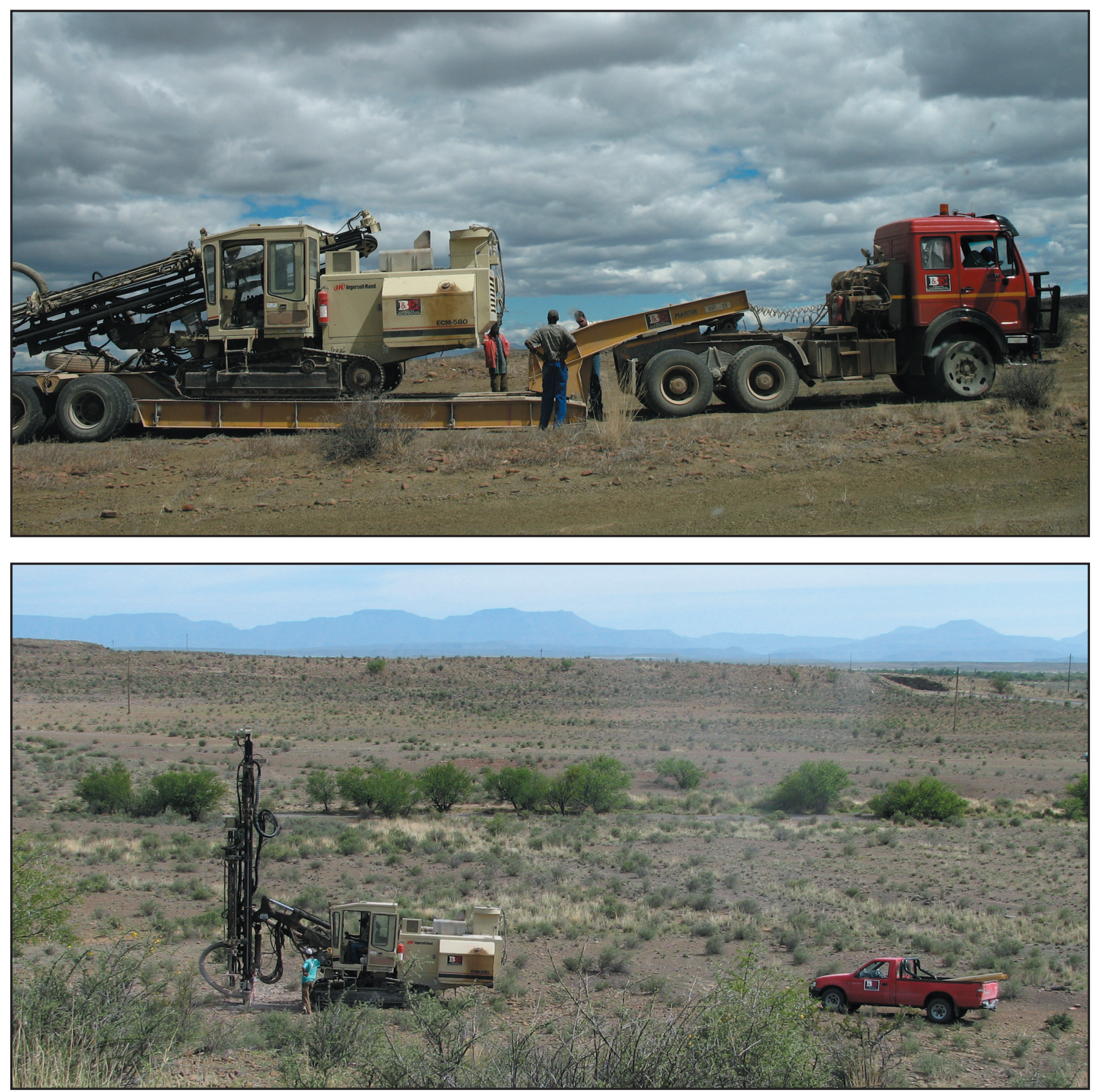

Figure 4. Field operations and instrumentation used: (a) $25 \mathrm{~m}$ long low-bed truck with drilling rig, (b) drilling on remote location

Figure 4 and Figure 5 represents a typical unprocessed data record from one shot.

In the centre of the NVR seismic line at Leeu Gamka (Figure 2a), 23 in-line shot points were lost due to land access difficulties and two other in-line shots did not detonate. To complete the source array via undershooting, 10 compensation shots were fired 0.3 to $1.5 \mathrm{~km}$ "off-line". The shot-point loss resulted in a small shallow V-shape data gap near the centre of the profile at shallow depths $(<1.5 \mathrm{~s}$ two-way-time (TWT) in the stacked and migrated sections. However, the deeper structures along this segment are well imaged and the maximum fold of 15-20 traces per CMP maintained.

\section{Data Processing}

The data acquisition technique yielded high-quality records that were processed at the GFZ-Potsdam using industry-based software ProMax. Data were recorded continuously and 20 second trace lengths were extracted to a construct a $\sim 100 \mathrm{~km}$ long and $>40 \mathrm{~km}$ deep crustal seismic reflection section. A second study analysed shallow velocity structure in the upper $\sim 1 \mathrm{~km}$ of the subsurface. The $\mathrm{Vp} / \mathrm{Vs}$ model that was derived from the tomographic inversion of first breaks/ refractions yields significant correlation with the surface geology (Bräuer et al. 2007).

The NVR seismic reflection processing obtained an optimum balance of parameters through iterative visual testing at each step in a conventional processing work flow (Table 3). In this preliminary processing stage, refraction statics were not computed because the unprocessed shot domain data did not show diagnostic 


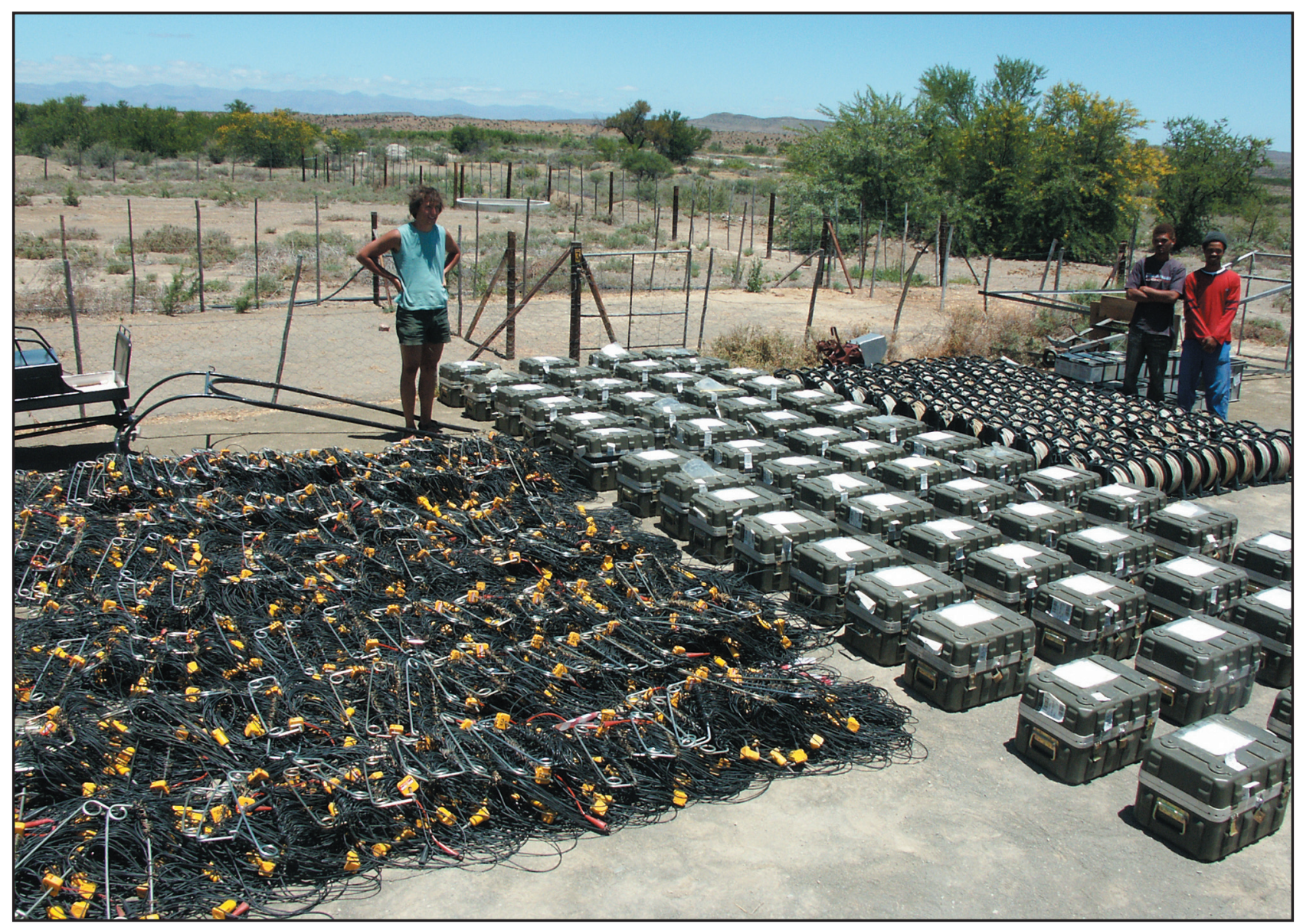

Figure 4. (c) geophysical instruments from the Geophysical Instrument Pool, Potsdam. From left to right: geophone strings, recorders, cables and batteries. Detailed parameters of the instruments and deployment technique are listed in Table 2.

strong time deviations in the reflection hyperbolas (which otherwise would indicate that statics should be applied). The high near-surface velocities caused small relative variations and consequent reduction of the corresponding statics to a negligible level. Testing of residual statics proved to be ineffective, perhaps related to the absence of a robust field statics solution and the statics solution may be refined in future work.

Special care was taken to remove noise originating from passing vehicles, $50 \mathrm{~Hz}$ power lines and dead traces. Surgical mutes proved useful to remove spikes and air-wave noise, while retaining most of traces. In the shot domain, the first $6 \mathrm{~s}$ TWT of unprocessed data are characterised by strong direct $\mathrm{S}$-wave signals, surface wave, air-blast and direct first P-wave arrivals, with strong shallow P-wave reflectors hidden in the noise (Figure 5). The visually balanced image shown in Figure 6 was obtained by suppressing the strong noise signals in the first few seconds while retaining energy from the underlying reflectors and enhancing the deeper reflections.

\section{Stacking}

The stacked seismic reflection image comprises 32088 traces stacked into 1044 common-mid-point (CMP) gathers. Each stacked CMP trace represents the sum of $\sim 20$ traces gathered from all shots and geophones with the same common-mid-point. A normal-move-out correction (NMO) velocity model was determined separately by extensive parameter testing, particularly in the upper $5 \mathrm{~s}$ TWT. Elevation statics corrected effectively for gentle topography of $<1 \mathrm{~km}$, but dip-move-out correction (DMO) and automatic-gaincontrol (AGC) were not successful in improving the stack.

An unmigrated CMP stacked section in the timedomain is shown in Figure 7. A clearly distinguishable series of continuous sub-horizontal flat reflectors occur along most of the profile from about $1 \mathrm{~s}$ TWT in the south to $3.5 \mathrm{~s}$ TWT in the north. This is in strong contrast with the less continuous reflectivity in the deeper crust.

A region of strong reflectivity is present near the expected location of the source of the BMA, at 3 to $5 \mathrm{~s}$ TWT and 55 to $65 \mathrm{~km}$ along the profile. Regions of higher reflectivity at 7 to $12 \mathrm{~s}$ TWT indicate complex internal structures in the mid-crust. Another region of moderate reflectivity occurs between 12 to $15 \mathrm{~s}$ TWT above a clearly defined lowermost reflector, which is interpreted as the Moho discontinuity.

A study by Gibson and Levander (1987) showed that dip-filtering of CMP stacks before migration resolves or suppresses the signal-generated noise effectively by reducing random noise and increasing the coherency of the reflections. A subsequent coherency enhancement 
Table 3. Summarised data processing parameters for the CDP line

\section{Processing parameters for CDP line}

\begin{tabular}{ll}
\hline & Read SegY data \\
\hline 3 & Hand statics \\
\hline 4 & Trace length \\
\hline 5 & Trace kill sequence \\
\hline 6 & True amplical trace mutes \\
\hline 7 & Deconvolution
\end{tabular}

$20 \mathrm{~s}$ trace length

clip first two seconds (background noise)

synchronise a few shot and time shifts define to $20 \mathrm{~s}$ noise from utility vehicles and dead traces mute spikes only in useful traces mute surface wave, ground roll and air wave

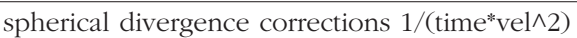
minimum phase predictive operator length $300 \mathrm{~ms}$ design gate

CDP 1000: 1000-5000, 5000-10000 ms CDP 3100: 1000-3000, 5000-15000 ms white noise $0.2 \%$

\section{$8 \quad$ Bandpass filter}

Ormsby minimum phase

10-15-40-45 Hz

remove $50 \mathrm{~Hz}$ noise from power lines

\begin{tabular}{ll}
\hline 9 & Air blast attenuation \\
\hline $10 \quad$ Time variant scaling
\end{tabular}

$\mathrm{v}=1550 \mathrm{~m} / \mathrm{s}$ and

$\mathrm{v}=2200 \mathrm{~m} / \mathrm{s}$ to suppress S-wave

time gate parameters in $\mathrm{ms}$ : t1: 0:0-1000, 20000:3500-4500

t2: 0:500-1500, 20000:4000-5000

t3: 0:1000-2000, 20000:4500-5500

t4: 0:1500-3000, 20000:5000-6500

t5: 0:2500-5000, 20000:6000-8500

t6: 0:4000-8000, 20000:7000-11000

t7: 0:7000-20000, 20000:10500-22000

$11 \quad$ F-K filter: remove $1000-5000 \mathrm{~m} / \mathrm{s} ; 0-45 \mathrm{~Hz}$

$-1000-5000 \mathrm{~m} / \mathrm{s} ; 0-45 \mathrm{~Hz}$

\begin{tabular}{lll}
\hline 12 & F-X decon & $10-50 \mathrm{~Hz}$ \\
\hline 13 & Air blast attenuation & re-apply v $=1550 \mathrm{~m} / \mathrm{s}$ \\
\hline 14 & CDP sort & nominal CDP fold 20 \\
\hline 15 & Elevation statics & final datum elevation $700 \mathrm{~m}$ \\
& & replacement velocity $4500 \mathrm{~m} / \mathrm{s}$ \\
\hline 16 & Normal move-out correction & stretch mute $80 \%$ \\
& & pre-determined nmo velocity model
\end{tabular}

17 Stack constant velocity stack tests

$4500 \mathrm{~m} / \mathrm{s}-8500 \mathrm{~m} / \mathrm{s}$

velocity samples 40

18 Coherency

dip scan stack aperture $15 \mathrm{~ms}$

min. dip -8, max dip 8

mean 0-18000 ms

Kirchhoff depth migration

CDP interval $50 \mathrm{~m}$

maximum frequency $50 \mathrm{~Hz}$

maximum depth $54 \mathrm{~km}$

maximum dip $40 \mathrm{deg}$

aperture $15 \mathrm{~km}$

velocity model from inversion tomography (Stankiewicz et.al 2007) 


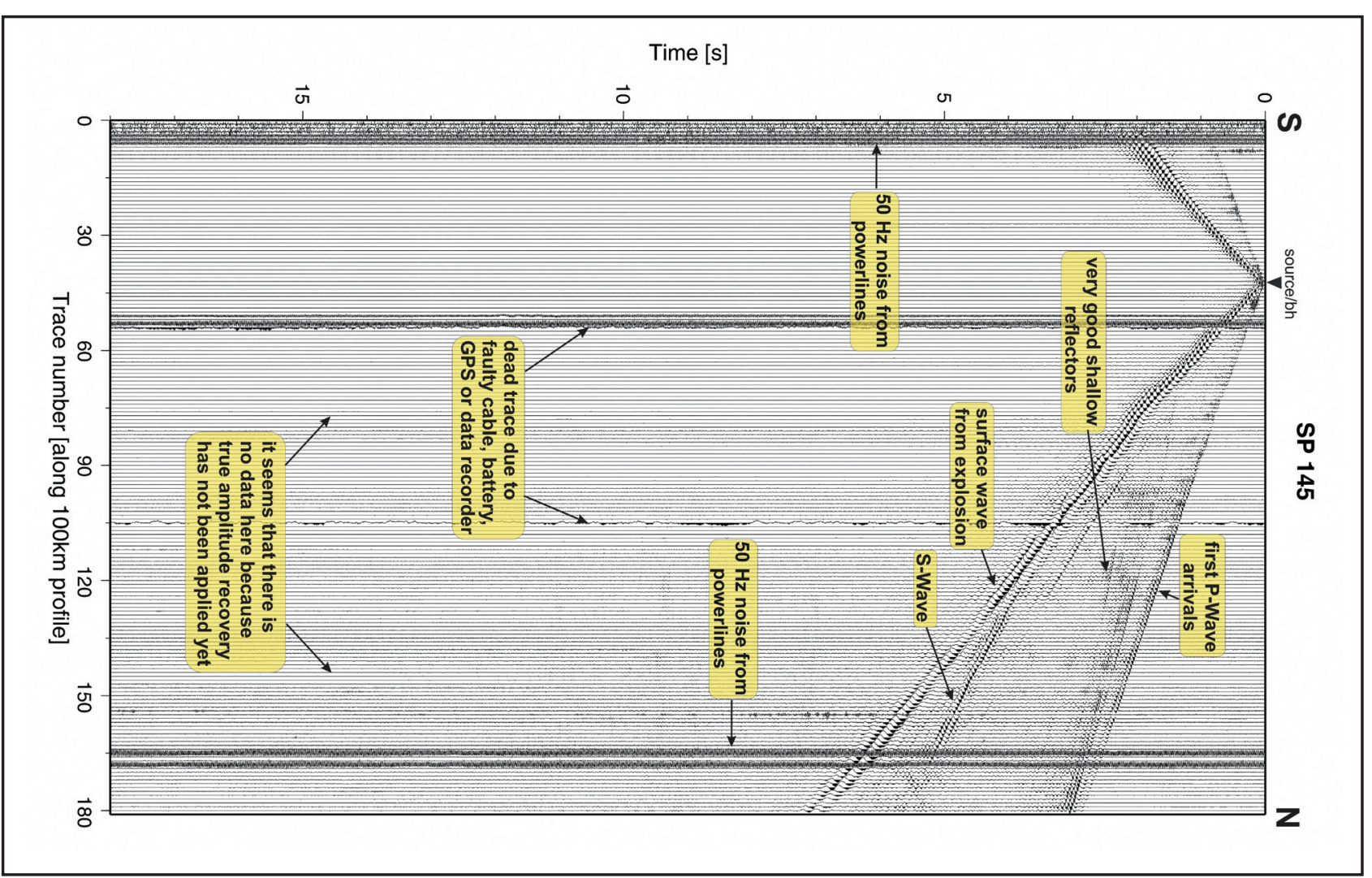

Figure 5. Unprocessed field record in single shot domain at shot point SP 145. Shallow P-wave reflections are clearly visible within the strong signals from the S-waves arrivals, but are obliterated in the centre by noise from the explosion. The signal-to-noise ratio is generally high. Trace spacing $\sim 100 \mathrm{~m}$.

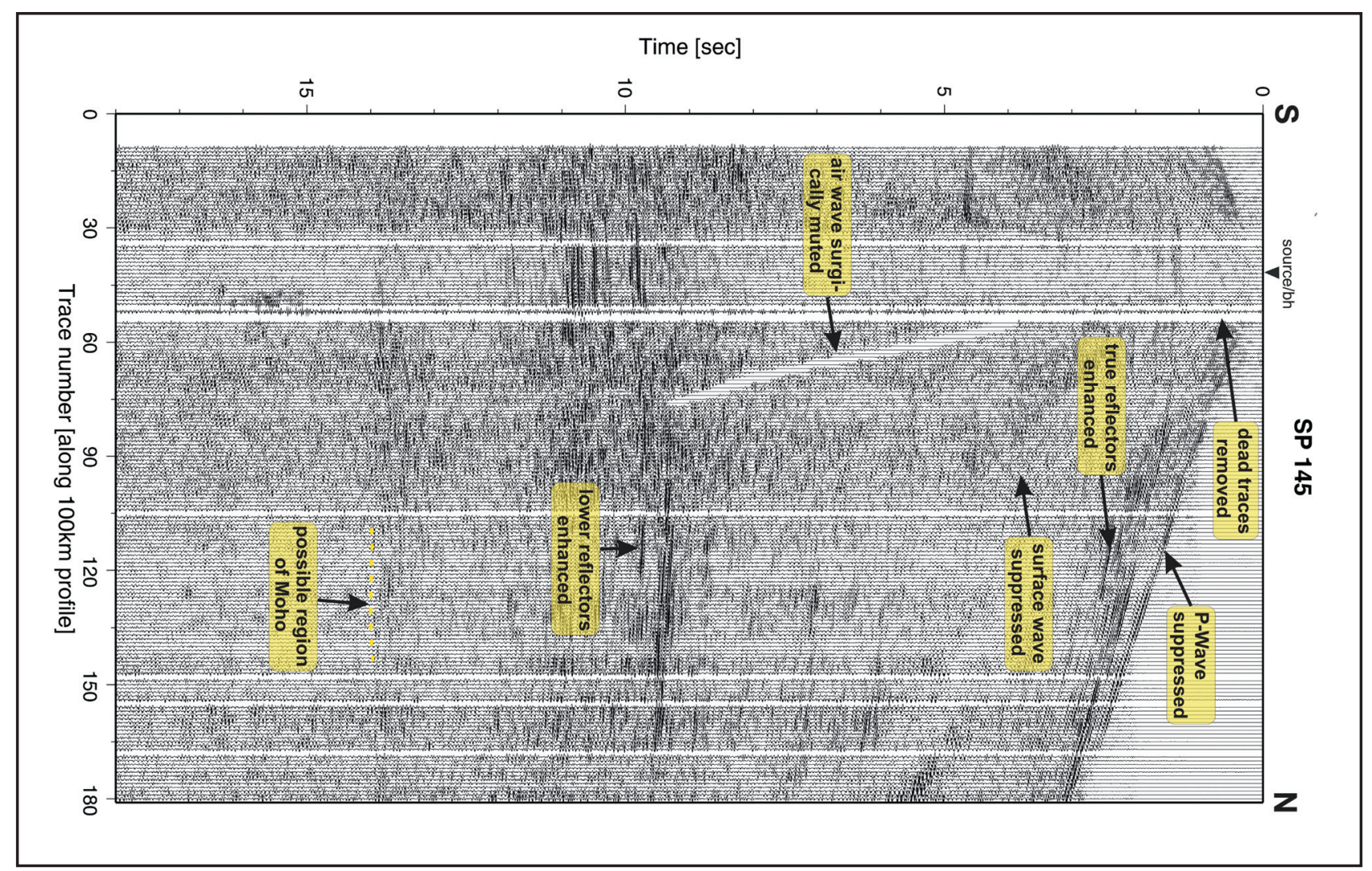

Figure 6. Processed record in single shot domain from point SP 145 with noise and dead traces removed. The trace amplitude corrections suppress the strong signals at the top and enhance smaller amplitudes from the deeper reflectors. In comparison with Figure 5, note that noise from the explosions (black lines near the top) is suppressed - while the lower blank part becomes more populated with coherent reflected energy. 
(dip scan filter) applied to the stacked data before migration, successfully improved the result of the migration and enhanced imaging of true discontinuous reflectors in the mid-crust.

\section{Migration}

Before interpretation of the data, a velocity model is needed for depth migration. In depth migration, reflection structures move to their correct depth and spatial position along the profile while the TWT scale is converted to a depth $(\mathrm{km})$ scale. Depth-migration velocity model trials were carried out using both an empirically derived stacking velocity model and a tomography model. The latter was derived from the tomographic inversion of P-wave arrivals from the coincident Wide Angle Refraction/Reflection seismic data experiment (Stankiewicz et al. 2007).

Tests were done in Stolt time-migrations, using higher (up to 110\%) and lower (down to 70\%) percentages of the tomography velocity model and comparing it with the stacking velocity model. The stacking velocity model only provides a limited migration solution because the picked velocities do not reflect the real rock velocities and are only valid at very shallow depth $(<4$ s TWT). Along the NVR profile, the tomography velocity model was constrained to a depth of $\sim 10$ to $20 \mathrm{~km}$ and the rest of the values down to the Moho inferred from the global crustal velocity model (Mooney et al. 1998). Comparisons between the stacking velocity model and tomography model showed no significant differences in the quality of the migration. The tomography model was chosen for a final depth migration. The final migration result is shown in Figure 8 and the migration parameters listed in Table 3 . Features under the CFB front, or those less than $100 \mathrm{~m}$ thick, or in the upper $2 \mathrm{~km}$ are not well resolved. The present velocity model result appears somewhat overmigrated in the deeper crust, but further refinement is in progress.

\section{Results and Interpretations}

Our data reveal a new detailed image of the continental crust and Moho under the Karoo Basin and BMA from which we derive a new simple preliminary model, shown in Figures 9 and 10. The NVR seismic image reveals a three-fold subdivision of the continental crust, with distinct reflective characteristics.

\section{Upper Crust}

An upper crust region of the Phanerozoic-Mesozoic Cape and Karoo Supergroup sedimentary rocks (annotated in pink, brown, yellow and red in Figure 9), increases in thickness from $\sim 5 \mathrm{~km}$ in the north to $\sim 10$ $\mathrm{km}$ in the south. The dipping reflectors near the surface (annotated in pink) are $\sim 5 \mathrm{~km}$ thick in the south and $\sim 2.5 \mathrm{~km}$ thick in the north, interpreted to represent the Karoo Supergroup. The continuous sub-horizontal gently south-dipping series of reflectors at 1.5 to $4 \mathrm{~s}$ TWT ( 2.5 to $10 \mathrm{~km}$ depth) represents undisturbed strata of the Cape Supergroup that display a gentle dip to the south. At the south end of the profile these basal sequences of the Cape Supergroup dip beneath the steeply overturned younger quartzites of the same group that define the seismically and structurally complex tectonic front of the Cape Fold Belt (CFB). This implies the existence of a significant thrust zone between two sequences and evidence of thin-skinned tectonics in the CFB.

A possible internal décollement occurs above the sub-horizontal continuous reflector package and separates the upper Karoo from the lower Karoo-Cape Supergroups. We interpret this décollement to occur along the carbonaceous shale of the Whitehill Formation (Table 1) as is sometimes observed in the field (e.g. Figure 34, p. 44 in Knütter, 1994), but details of the thrust structure were not resolved in the seismic image. The interpreted position of the Whitehill Formation in the seismic image is in good agreement with the work of Cole and McLachlan (1994) who reported $\sim 35$ to 44 $\mathrm{m}$ thick Whitehill Formation at top-depths of $\sim 2016 \mathrm{~m}$ and $3391 \mathrm{~m}$ in boreholes SA1/66 and KW1/67, respectively (Figures $2 \mathrm{a}$ and 9). Additional borehole stratigraphic correlations are ongoing.

\section{Mid-Crust}

A seismically defined unconformity separates the subhorizontal continuous Karoo-Cape sediment sequences that truncate steeper dipping reflectors in a well defined mid-crustal layer, which also hosts the BMA (Figure 9). The mid-crustal layer directly beneath the unconformity at the base of the Cape Supergroup displays discontinuous zones of strong reflectivity and a seismic fabric dip, which is distinctly different from the upper and lower crust. The different dip directions of the seismic fabrics in the mid- and lower crustal layers suggest that these two layers have different geological histories.

The mid-crust seismic fabric (green lines in Figure 9) dips steep to the north and is interpreted as a tectonic fabric (foliation) or tectono-metamorphic layering related to stacked crustal wedges. The internal fabric of this mid-crust layer is abruptly truncated against the unconformity at the base of the Cape Supergroup (e.g., Figure 10). Its northerly dip is in contrast with previous geological models that postulate a dip of the tectonic fabric to the south (e.g., Hälbich 1993, Figure 3).

We infer that the mid-crust layer is likely to represent a subsurface continuation of the Bushmanland terrane of the NNOB. This is consistent with drill core samples below the Karoo, drilled through the Cape-Karoo sequence (e.g., Eglington and Armstrong 2003). From this borehole data we also know that there are no sedimentary rocks in the mid-crust layer below the unconformity but only the gneisses of the high grade Namaqua-Natal metamorphic basement. The interpreted tectonic fabric of the mid-crust layer therefore does not represent strata of sediments (such as Pan African rocks 


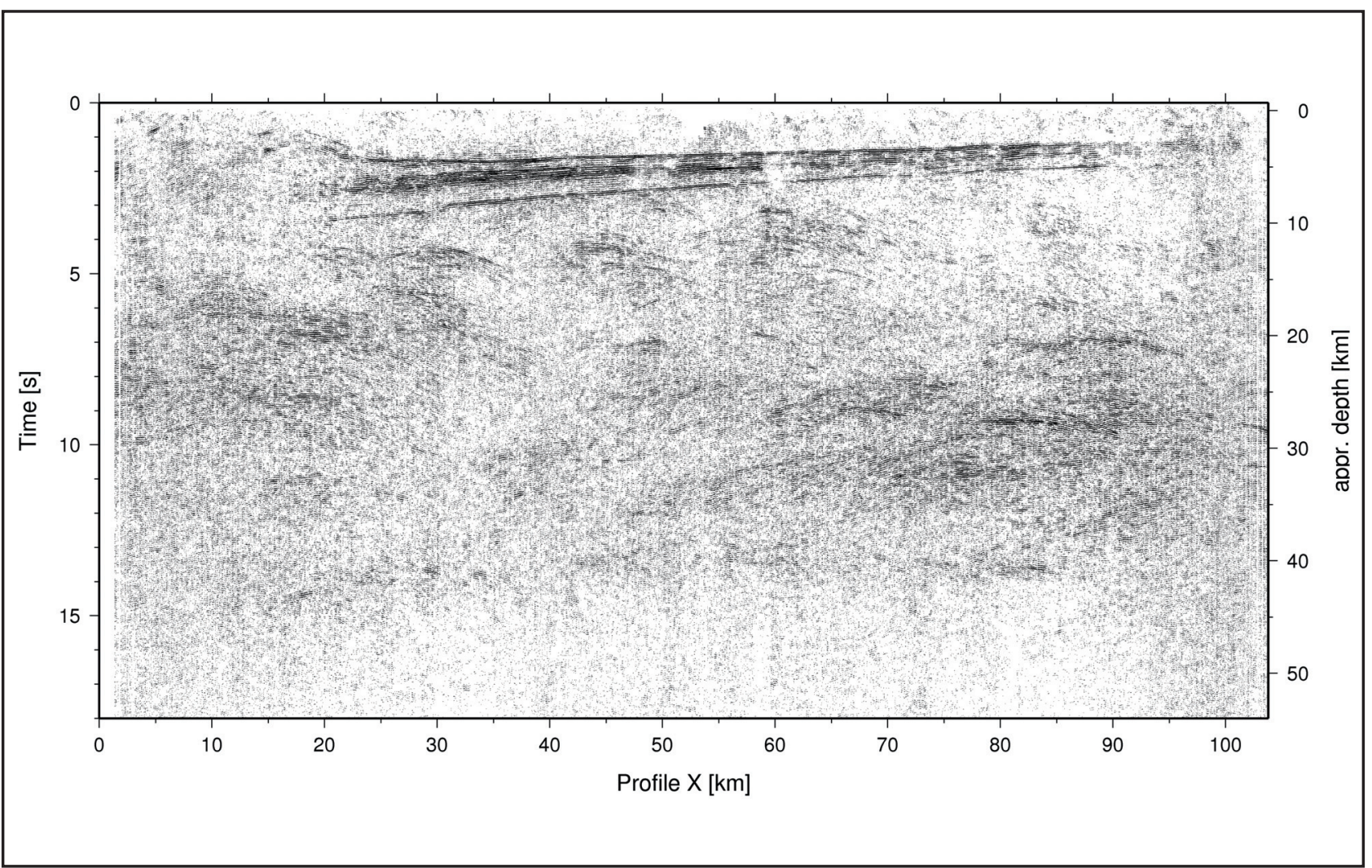

Figure 7. Un-migrated common-mid-point (CMP) stacked section in time domain. No coherency dip-scan- filter was applied and CMP trace interval is $50 \mathrm{~m}$. A series of shallow, continuous, slightly south dipping reflectors occur along most of the profile at approximately 1.5 to $3.5 \mathrm{~s}$ TWT. This package is very different from the deeper reflections. A region of strong reflectivity outlines the expected region of the BMA, at $5 \mathrm{~s}$ TWT and 55 to $65 \mathrm{~km}$ along the profile. Note the zone of higher reflectivity flanking the BMA to the left - see text for further explanation. Strong reflectivity occurs down to 12 to $15 \mathrm{~s}$ TWT. The Moho is detected intermittently around $15 \mathrm{~s}$ TWT.

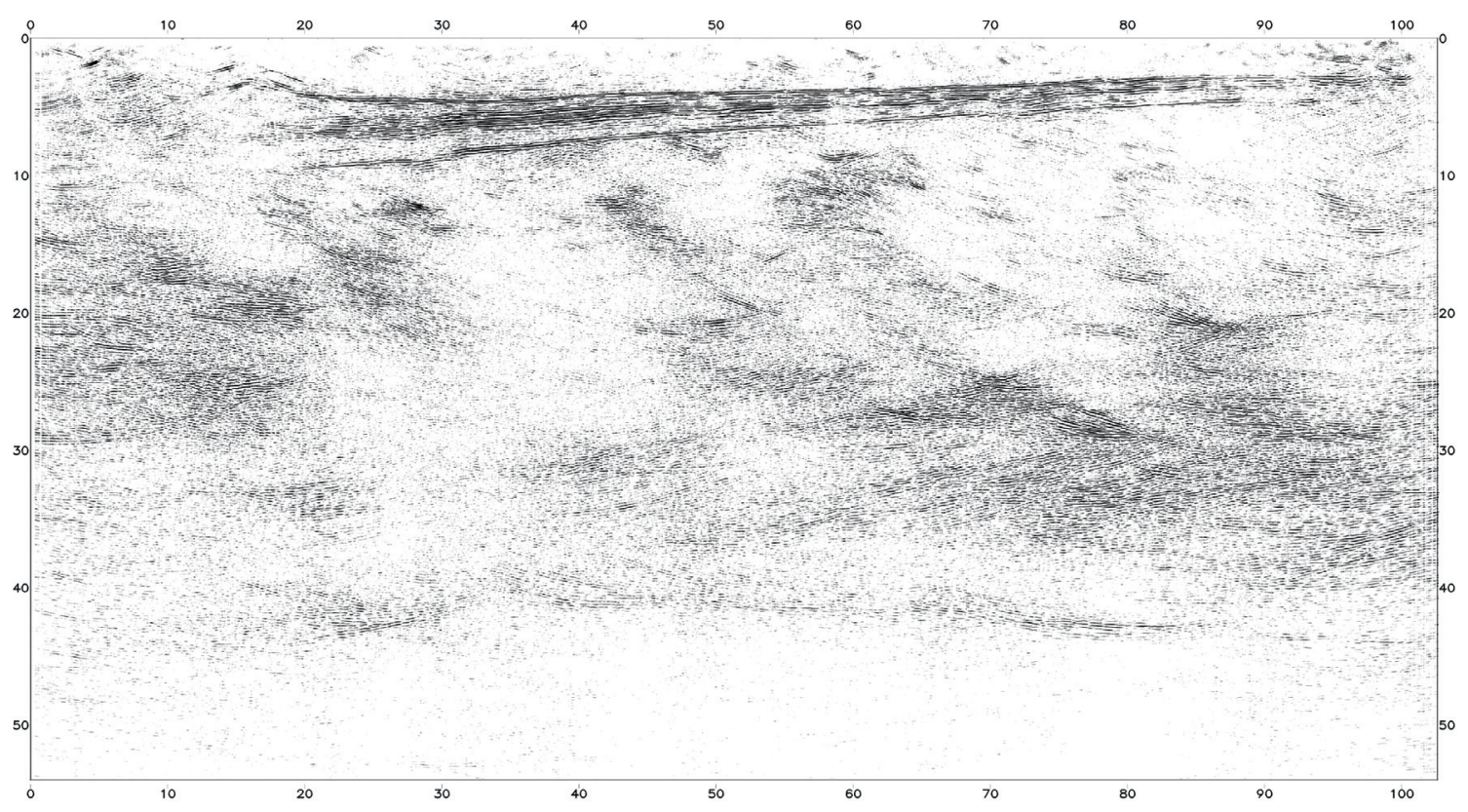

Figure 8. Migrated CMP section in depth domain with coherency (dip-scan filter) applied before migration. Note regions with complex distinct reflective characteristics in the upper, middle and lower crust became narrower and moved to approximate depth positions. The Moho is clearly imaged at 42 to $45 \mathrm{~km}$. 


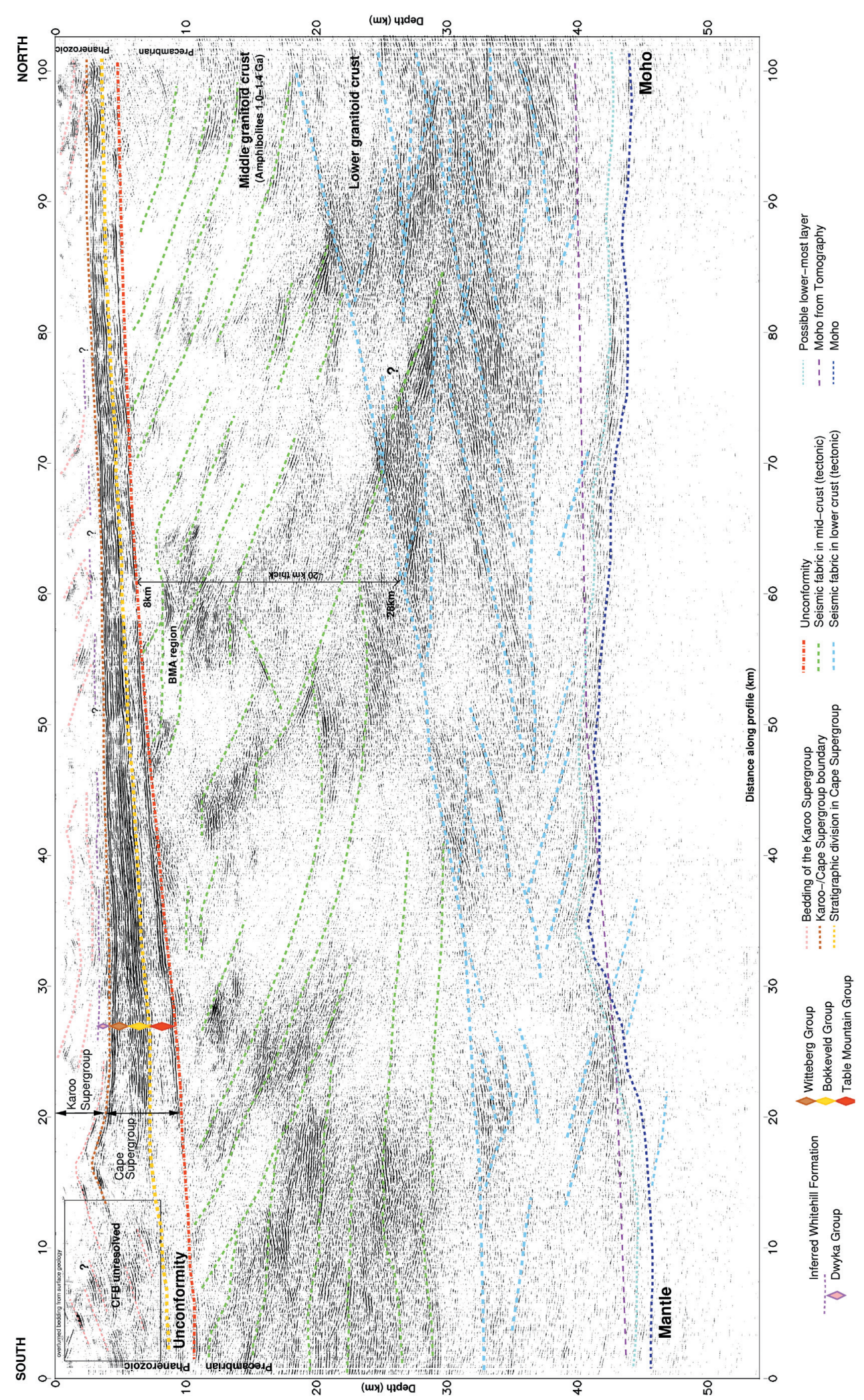

Figure 9. Interpretation of the CMP migrated section and three fold subdivision of the continental crust: the upper crust region above the sub-horizontal reflectors show dipping strata (annotated in pink) of the Karoo Supergroup. Note the possible décollement near the base of this sequence. The uppermost continuous reflectors (yellow and orange) represent 5 to 10 km thick Phanerozoic Cape Supergroup sediments with a shallow dip to the south. An unconformity separates the upper crust from north dipping mid-crust granitoid gneisses of the NNOB (green). The lower crystalline crustal slab (blue lines) displays an internal fabric that dips both to the north and south, but predominantly to the north. The boundary between the mid- and lower-crustal sections is not well defined. Reflectivity $\sim 1$ to 2 km above the undulating Moho depth suggests a possible additional layer. The interpreted Moho is in agreement with the Moho derived from tomography data (Stankiewicz et al. 2007). 
inferred to underlie parts of the Cape Fold Belt) and as such, cannot accommodate an alternative interpretation that the north dipping fabric in this mid-crust layer is due to bedding of sedimentary rocks separated by $\sim 45$ degree south-dipping faults, as suggested in previous models.

\section{Lower Crust}

The top of a lower crystalline crustal layer occurs at $\sim 19 \mathrm{~km}$ depth in the north and $\sim 33 \mathrm{~km}$ depth in the south of the NVR seismic section (blue lines in Figure 9). The lower wedge-shaped layer ranges in thickness from $\sim 12 \mathrm{~km}$ in the south to $\sim 24 \mathrm{~km}$ thick in the north, and displays an internal seismic reflection fabric that dips moderately north and south, and predominantly north towards the base of this crustal layer. The north-south dipping fabric suggests a tectonic history of extension and compression. The boundary between the mid and lower crustal section is not well defined, especially in the centre of the section where the mid-lower crustal seismic reflectors are not clearly differentiated. At present, we interpret the mid/lower crust boundary as a tectonic mid-crustal detachment between the Bushmanland layer above and the crystalline layer below. This interpretation is consistent with a regional model of late regional extension and detachment between the Bushmanland terrane and the underlying Namaqua terrane (e.g., Dewey et al. 2006). On this basis, the lower crustal section is likely to represent the equivalent of the Namaqua terrane granulites.

A clear, continuous, gently south-dipping Moho is observed at a depth between $\sim 42$ and $45 \mathrm{~km}$, consistent with a Moho at $\sim 42 \mathrm{~km}$ determined by Green and Durrheim (1990) in a region $>300 \mathrm{~km}$ to the northwest in the NNOB (Figure 2b) and also compares well with the receiver function study of Harvey et al. (2001) that reported a Moho depth at 40 to $45 \mathrm{~km}$ at station $\mathrm{SA} 05, \sim 50 \mathrm{~km}$ to the west of this seismic line (Figure 2a). The Moho undulates slightly with a nick point at $\sim 42 \mathrm{~km}$ depth, $\sim 35 \mathrm{~km}$ along the profile, and deepens to $\sim 45 \mathrm{~km}$ under the Cape Fold Belt in the south. Increased reflectivity in the lowermost $\sim 1$ to $2 \mathrm{~km}$ above the Moho (Figures 9 and 10) suggests a compositional differentiation or underplating, and may represent a layer of mafic gneiss. This is consistent with a model that postulated underplating of the NNOB crust by basalts during regional extensional tectonics at $\sim 1.0 \mathrm{Ga}$ in Namaqualand (e.g., Dewey et al. 2006).

Our results of $\sim 43$ to $45 \mathrm{~km}$ total crustal thickness agree well with other studies: 42 to $50 \mathrm{~km}$ Harvey et al. (2001) over the Karoo Basin and Kaapvaal craton; 38 to $51 \mathrm{~km}$ of Wright et al. (2003) and 38 to $43 \mathrm{~km}$ (Kwadiba

S

New simplified model from NVR seismic data

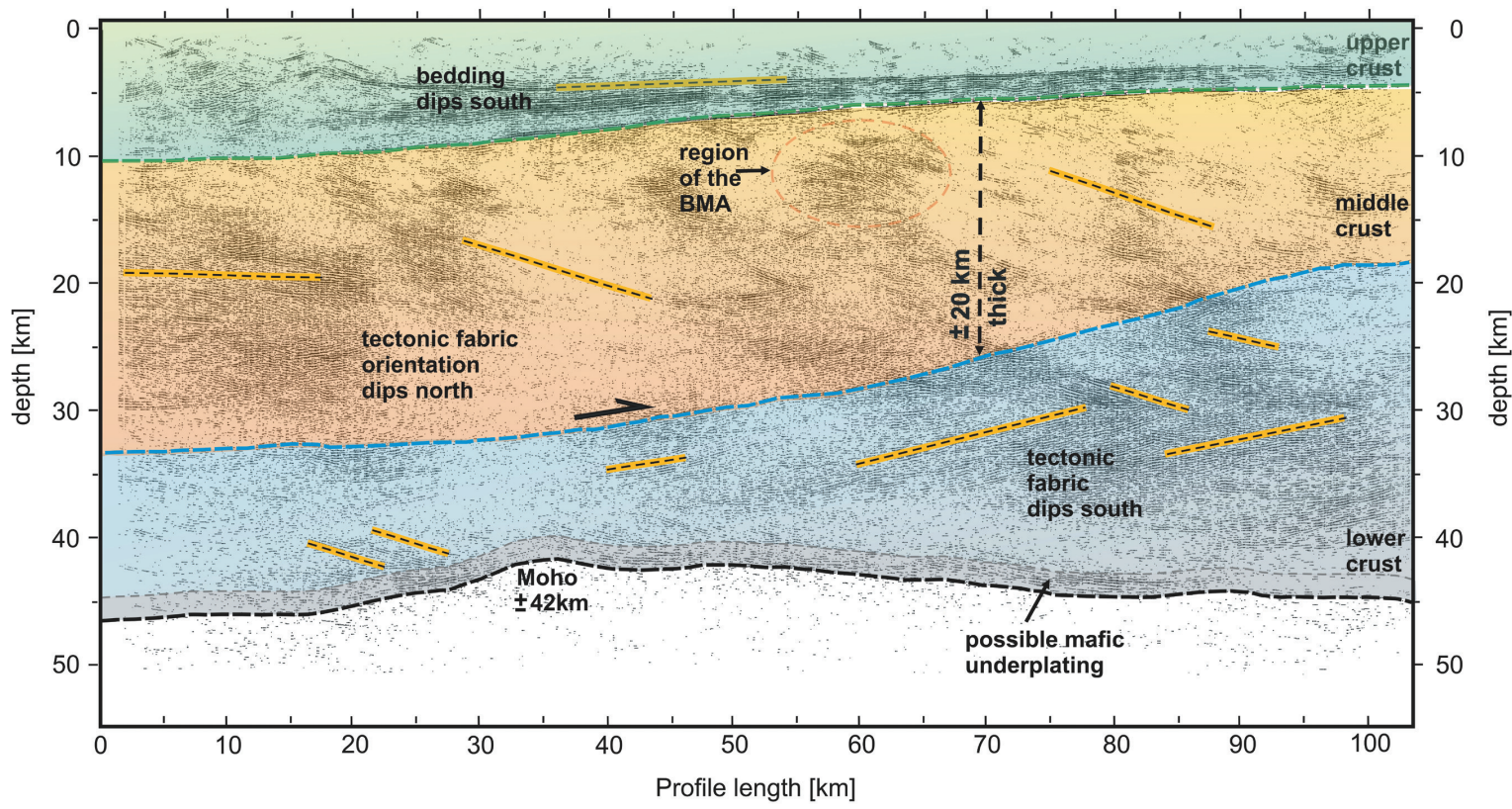

Figure 10. Preliminary simplified tectonic model. The three subdivisions of the crust are shown in green, orange and blue. Dip direction of the seismic fabric (interpreted as a tectonic structure) is shown by the yellow and black dashed lines. The unconformity between upper crustal sequences and the crystalline mid-crust is indicated by the green dashed line. The dominant middle crust tectonic fabric dips north. This is in contrast to the previous model (Figure 3) that postulates a tectonic fabric that dips to the south. The region of the BMA source, Moho and the thin overlying layer are also indicated - see text for further explanation. 
et al. 2003) on the southern part of the Kaapvaal craton. However, in our NVR data, we do not observe a sharp change in Moho depth at the CFB front as suggested by Harvey et al. (2001), but image a Moho that dips gently deeper below the CFB tectonic front. This is probably due to the much better lateral and vertical resolution of the NVR seismic image.

\section{The BMA}

On the seismic image, the BMA appears confined to the upper part of the $\sim 20 \mathrm{~km}$ thick postulated NNOB mid-crust layer (Figure 9). The source of the BMA is therefore likely to be related to the make-up of the Bushmanland terrane. The orientation and character of the inferred tectonic fabric around the BMA region ( $\sim 60 \mathrm{~km}$ along profile length in Figures 8, 9 and 10) does not appear very different from that of its surroundings. The reflectors around the inferred region of the BMA are confined to a narrow zone $\sim 10$ to $20 \mathrm{~km}$ wide, at 7 to $15 \mathrm{~km}$ depth, and do not extend farther than $15 \mathrm{~km}$ from there into the mid- and lower crusts. We infer, therefore, that along this profile the probable BMA source is confined to a narrow feature in a structurally complex region in the Bushmanland crystalline basement, at a depth of 7 to $15 \mathrm{~km}$ and $\sim 10 \mathrm{~km}$ wide, at a distance of $\sim 60 \mathrm{~km}$ from the south end of the profile (Figures 9 and 10). We find no evidence in the reflectivity patterns that would support a deeper extension of the BMA here as a serpentinised suture zone (ophiolite model) as previously suggested (De Beer et al. 1982; Hälbich 1993; Pitts et al. 1992).

Comparison between the NVR seismic image and a seismic tomographic model of the upper crust (Stankiewicz et al. 2007) reveals good agreement (Figure 11). Low seismic velocities ( 4.6 to $5.3 \mathrm{~km} / \mathrm{s}$ in red and orange), interpreted as Karoo sedimentary rocks, are underlain by higher velocities $(5.4$ to $5.8 \mathrm{~km} / \mathrm{s}$ yellow-pale green) interpreted as Cape Supergroup quartzites. The abrupt change in velocities coincides with the horizontal continuous reflectors which marks a seismic discontinuity, interpreted as an unconformity between the sedimentary rocks of the upper crust package and metamorphic rocks of the underlying Mesoproterozoic NNOB mid-crust. The NVR seismic image does not, however, reveal a blind thrust fault as interpreted on the tomographic section (Stankiewicz et al. 2007).

In the tomography model, the high velocity region near the inferred BMA source appears broader $(\sim 10 \mathrm{~km}$ deep and $\sim 250 \mathrm{~km}$ wide) than the zone of strong reflectivity on the NVR seismic image (Figure 11a). However, given the resolution of the tomographic results, the correspondence between the NVR seismic image and velocity structure is reasonable. On the NVR image, a second $\sim 5 \mathrm{~km}$ wide reflective zone occurs farther to the south, at similar depth (Figures 8, 9 and 10), and this could indicate a greater extent of the inferred BMA source. This is consistent with the observation that near these two zones of higher reflectivity the BMA appears to widen and "split" as reflected on the aeromagnetic map (Figures $2 \mathrm{a}$ and c). Additional seismic lines over the BMA might resolve this further.

The accompanying magnetotelluric transect has imaged low resistivity of approximately $1 \Omega \mathrm{m}$ in the region of the inferred BMA source, at 5 to $10 \mathrm{~km}$ depth (Weckmann et al. 2007a; b). This result is superimposed on the seismic image for direct comparison in Figure 11. The lower resistivity in the region of BMA correlates very well with the complex seismic reflectivity zone identified in the NVR seismic image (Figures 8 and 9). A higher resistivity region at $\sim 25 \mathrm{~km}$ depth correlates with the NVR defined division between middle and lower crust.

\section{Global Analogies}

From available global seismic reflection sections across similar age terranes, the Lithoprobe sections in Canada (Clowes et al. 1996, White et al. 2000) provide the best public domain work with which to compare our section. Transects that cross the Grenville Orogen, which has been directly correlated to the NNOB (e.g., Hofmann 1991; Jacobs et al., 1993; Dewey et al. 2006 and references therein) are particularly relevant. The reflectivity patterns observed in the Lithoprobe transects are similar to those seen in the Karoo NVR seismic line. Further detailed comparative work of the seismic images and interpreted models is in progress, but it seems appropriate to draw attention here to some first-order seismic reflectivity similarities observed between our data and two Lithoprobe transects:

1. The Lithoprobe SNORCLE transect consists of $\sim 2600 \mathrm{~km}$ seismic reflection data across the $\sim 1.9$ to 1.8 Ga Wopmay tectonic terrane and continental scale magnetic anomalies (Cook et al. 2004; 2005; Evenchick et al, 2005). The Wopmay tectonic terrane and magnetic anomalies are of similar age than the $\mathrm{NNOB}$ and BMA. Although the interpretation from Cook et al. (2004; 2005) is slightly different from Evenchick et al. (2005), their seismic lines (1, 2a, 2b and 3) image prominent sub-horizontal continuous reflectors in the upper $5 \mathrm{~s}$ TWT and an abrupt change into zones of coherent dipping reflectors in the midcrust layer. These mid-crustal reflectors truncate against sub-horizontal continuous reflections above and a wedge-shaped lower crustal layer below. Similar to our NVR section, seismic reflectors in the lower crustal layer have a different dip orientation from reflectors in the mid-crust layer.

2. The Lithoprobe Abitibi-Grenville transect seismically tracks the transition of the high grade Mesoproterozoic Grenville terrane gneisses, in a tectonic thrust contact across the Archean Superior Province craton (Ludden and Hynes, 2000). Similarly, the NVR seismic line tracks the NNOB that is thrust across the Archean Kaapvaal Craton (Figure 2b). The Grenville section also reveals internal seismic discontinuities, abrupt changes in overall reflectivity and "angular unconformities" between apparent dips of reflectors 


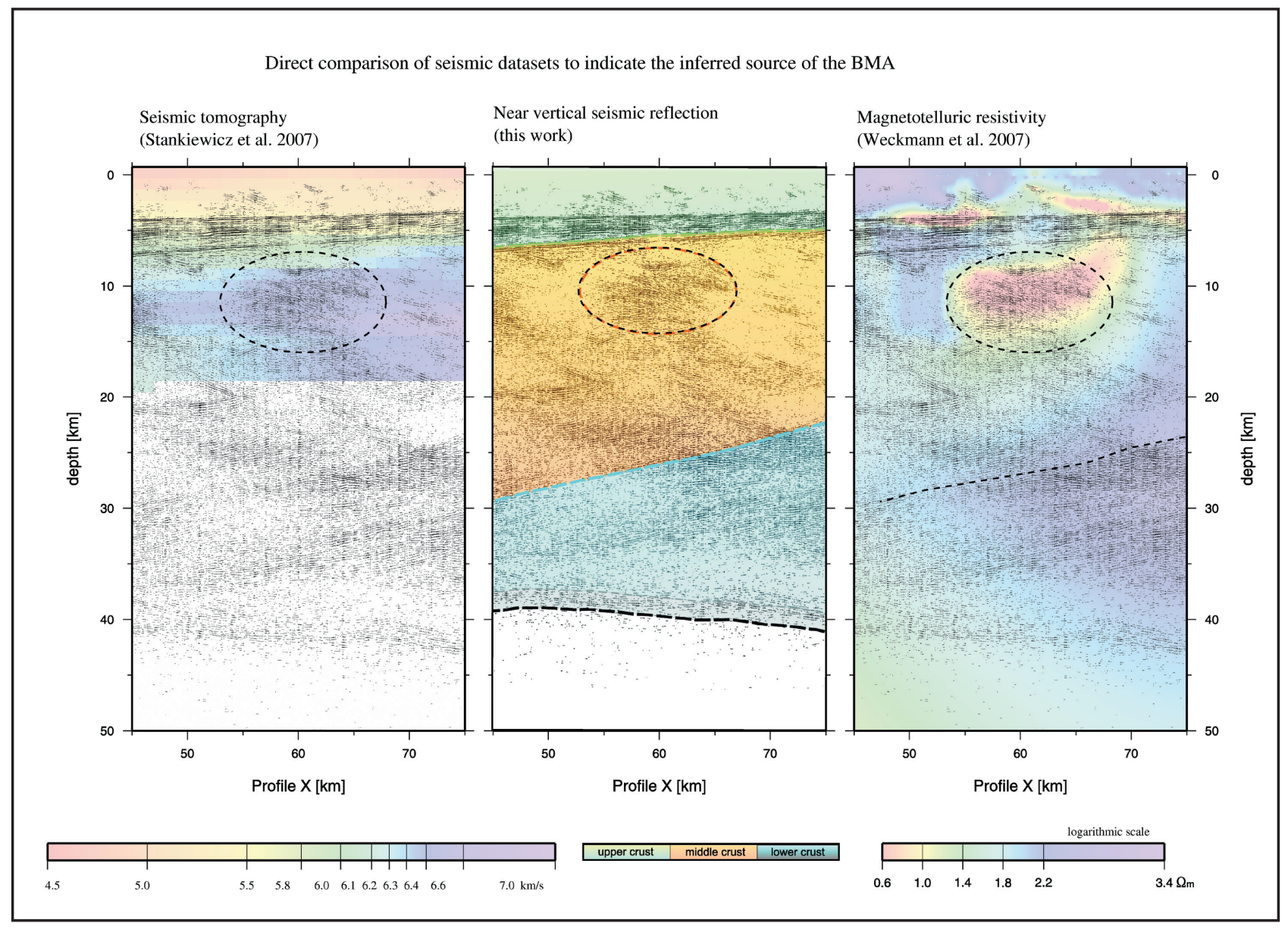

Figure 11. Comparison of three datasets along the transect in the direct vicinity of the BMA, between 45 to $75 \mathrm{~km}$ along the profile. From the left (a) Migrated NVR section and an overlay of the velocity model derived from Wide Angle seismic tomography inversion (Stankiewicz et al. 2007), (b) Migrated NVR section and overlay of new geological interpretations (this paper) (c) Migrated NVR section and overlay with magnetotelluric data (Weckmann et al. 2007a; b). Higher tomographic velocities and lower MT resistivity appear to correlate with the NVR seismic image in the same BMA source region ( 55 to $65 \mathrm{~km}$ along profile length and 7 to $15 \mathrm{~km}$ depth) - see text for further explanation.

in adjacent crustal blocks that resemble those seen in the presently described section of the NNOB. In addition, the large scale layering of the NNOB and the Grenville crust both have a three-fold crustal subdivision: a highly reflective upper crust, a transparent intermediate crust and a more reflective lower crust, underlain by a strong coherent lowermost reflector that defines the Moho (e.g., compare seismic sections in Ludden and Hynes, 2000; lines 53 to 54 in Martignole et al. 2000; White et al. 2000, with the present data).

\section{Conclusions}

A near vertical reflection profile provides the first clear seismic image of a $\sim 100 \mathrm{~km}$ long crustal section below the Karoo Basin, the frontal section of the Cape Fold Belt, and the basement region around the Beattie Magnetic Anomaly. The observed crustal components are:

- A highly reflective 42 to $45 \mathrm{~km}$ thick crust comprising three distinct layers: the upper, middle, and lower crust that is bound by a sharp crust-mantle transition at the Moho. A possible thin fourth lower-most layer straddles the Moho.
- The upper crust is represented by an uppermost series of variably dipping reflectors that represent the deformed sequences, of the Karoo Basin. These are underlain by a more uniform and gently southdipping sequence of continuous reflectors that represent the sedimentary rocks of the Cape Basin.

- A discontinuous décollement in the Whitehill Formation is located at a depth of 2.5 to $5 \mathrm{~km}$ along the length of the entire profile up to and less clearly within the Cape Fold Belt front.

- The seismic image reveals no significant stratigraphic thickening of the Karoo basin towards the CFB tectonic front as postulated on geological grounds (e.g., Cole, 1992; Catuneanu et al. 1998). The significant flexural component across the basin (e.g., Cloetingh et al. 1992; Milani and de Wit, 2007) therefore needs further analyses.

- An unconformity at $\sim 5$ to $10 \mathrm{~km}$ depth marks the contact between the Phanerozoic Cape Sequence above and the crystalline Mesoproterozoic basement of the NNOB crust below.

- A postulated mid-crust crystalline basement with distinctive zones of higher and lower reflectivity patterns represent a series of south verging stacked 
wedges of NNOB amphibolite granulite gneisses that are probably the equivalent of the Bushmanland terrane. The internal seismic fabric, inferred to be a tectonic fabric, dips to the north, and not to the south as inferred by previous researchers.

- The 12 to $24 \mathrm{~km}$ thick lower crust with an internal south and dominantly north dipping fabric, may be correlated with the Namaqua terrane of the NNOB. A subdivision seems plausible with tectonic fabric of the lower part mostly dipping to the north.

- A possible tectonic detachment occurs between the mid- and lower-crust layers.

- The 1 to $2 \mathrm{~km}$ thick lowermost layer parallel to the Moho may represent mafic underplating during extensional tectonics of the NNOB.

- The depth to the Moho is well-defined and ranges from $\sim 45 \mathrm{~km}$ in the north to $\sim 42 \mathrm{~km}$ in the south

- The magnetic source of the BMA can be correlated with a distinctive zone of high seismic reflectivity and appears confined to a narrow $10 \mathrm{~km}$ wide and 7 to $15 \mathrm{~km}$ depth region in the newly defined crystalline layer of mid-crust. Along the present seismic section, it seems unlikely that the BMA represents a deep master suture zone that penetrates the entire crust.

- The new NVR seismic work presented in this paper does not display evidence to support the existence of a mid-crust ophiolite wedge or a south-dipping thrust model for the tectonic evolution of the study regions (e.g., Hälbich et al. 1983; 1993; Pitts et al. 1992)

- An inferred BMA source region is well-correlated with complimentary Wide Angle Refraction and Magnetotelluric experiments.

Collectively, the initial results of these experiments are consistent with a complex Mesoproterozoic geologic history of the crystalline crust prior to the deposition of the overlying Phanerozoic-Mesozoic Cape and Karoo Basins. There is no obvious evidence from the seismic data that supports the occurrence of significant Pan African basement as is inferred to occur to the south of the $\mathrm{CFB}$ in the footwall of major normal listric faults (e.g., Stankiewicz et al. 2007; Hälbich et al. 1983; 1993).

The tectonic history that produced the domains of contrasted seismic tectonic fabric is not yet completely understood. But since the section bears good resemblance to transects across the Mesoproterozoic Grenville Province of Canada, further comparative analysis may shed more light on the tectonic history of the NNOB basement under the Karoo. We will in future test how the Grenville crustal velocity information (Winardhi and Mereu, 1997) affects our migration result. Other future velocity migration tests may include the Wamer (1987) approach, that could involve up to a $50 \%$ reduction of the deep crust velocities for migration, and comparative depth migration using velocity models from the west coast NNOB line (Green and Durrheim 1990), the Agulhas-Karoo onshore/offshore transect velocities at the continent-ocean transition, (Parsiegla et $a l, 2007)$, and the west coast onshore/offshore wide- angle seismic line acquired by GFZ/BGR/CGS (Mahanyele et al. 2004). This future work will still have its limitations because geology and tectonics occur in 3D. Hence without a 3D survey and borehole control, a 2D migration on a single NVR seismic line will not be able to resolve the imaging adequately.

\section{Acknowledgements}

Funding for the field work was provided by the GeoForschungsZentrum (GFZ) Potsdam (Germany), the Council for Geoscience Western Cape Unit in Cape Town (CGS), and the South African National Research Foundation (NRF). The geophysical instruments were provided by the Geophysical Instrument Pool Potsdam (GIPP). A. Lindeque would like to thank the CGS, GFZ, and NRF for funding her data processing at GFZ Potsdam, Germany and Karoo field work. We thank the field team and all the participating Karoo farm owners for generous hospitality and access to their land. Special thanks to Ariane Siebert at GFZ Potsdam for assistance with the figures. The manuscript benefited from the input of George Smith, as well as constructive and detailed reviews from Ron Clowes and Mark Muller. This is AEON contribution 39 and Inkaba yeAfrica contribution number 22 .

\section{References}

Barnett, W., Armstrong, R. and de Wit, M. (1997) Stratigraphy of the upper Neoproterozoic Kango and lower Paleozoic Table Mountain Groups of the Cape Fold Belt, revisited. South African Journal of Geology, 100, 237-250. Barret, S.D. (1993) The African Mapping Project. International Institute for Aerospace Surveys and Earth Sciences, Special Issue, 2, 122-131.

Beattie, J.C. (1909). Report of a magnetic survey of South Africa. Royal Society of London Publication, Cambridge University Press, United Kingdom.

Bräuer, B., Ryberg, T. and Lindeque, A.S. (2007) Shallow seismic velocity structure along the Prince Albert Slingersfontein profile. South African Journal of Geology, 110, 439-448.

Broquet, C.A.M. (1992) The sedimentary record of the Cape Supergroup: A review. In: M. J. De Wit and I.D.G. Ransome (Editors). Inversion tectonics of the Cape Fold Belt, Karoo and Karoo and Cretaceous basins of Southern Africa, Balkema, Rotterdam, Netherlands, 159-184.

Catuneanu, O., Hancox, P.J. and Rubidge, B.S. (1998). Reciprocal flexural behaviour and contrasting stratigraphies: a new basin development model for the Karoo retroarc foreland system, South Africa. Basin Research, 10, $417-439$

Chevallier, L. and Woodford, A. (1999). Morpho-tectonics and mechanism of emplacement of the dolerite rings and sills of the western Karoo, South Africa. South African Journal of Geology, 102, 43-54.

Cloetingh, S., Lankreijer, A., de Wit, M.J., and Martinez, I. (1992). Subsidence history analyses and forward modelling of the Cape and Karoo Supergroups. In: M. J. De Wit and I.D.G. Ransome (Editors). Inversion tectonics of the Cape Fold Belt, Karoo and Karoo and Cretaceous basins of Southern Africa, Balkema, Rotterdam, Netherlands, 239-248.

Clowes, R.M., Calvert, A.J., Eaton, D.W., Hajnal, Z., Hall, J. and Ross, G.M. (1996). LITHOPROBE reflection studies of Archean and Proterozoic crust in Canada. Tectonophysics, 264, 65-88.

Cole, D.I. (1992). Evolution and development of the Karoo Basin. In: M. J. De Wit and I.D.G. Ransome (Editors). Inversion tectonics of the Cape Fold Belt, Karoo and Karoo and Cretaceous basins of Southern Africa, Balkema, Rotterdam, Netherlands, 23-26.

Cole, D.I. and McLachlan, I.R. (1994) Oil Shale Potential and Depositional Environment of the Whitehill Formation in the Main Karoo Basin. Internal Report No. 1994-0213. Council for Geoscience, Pretoria, South Africa. $146 \mathrm{pp}$. 
Cook, F.A., Clowes, R.M., Snyder, D.B., Van der Velden, A.J., Hall, K., Erdmer, P. and Evenchick, C.A. (2004). Precambrian crust and lithosphere beneath the Mesozoic Northern Canadian Cordillera discovered by LITHOPROBE seismic reflection profiling. Tectonics, 23 doi:10.1029/2002TC001412.

Cook, F.A., Hall, K.W., and Lynn, C.E. (2005). The edge of northwestern North America at 1.8Ga. Canadian Journal of Earth Science, 42, 983-997.

De Beer, J.H. and Gough, D.I. (1980). Conductive structures in southernmost Africa: A magnetometer array study. Geophysical Journal of the Royal Astronomical Society, 63, 479-495

De Beer, J.H. and Meyer, R. (1983). Geoelectrical and gravitational characteristics of the Namaqua-Natal Mobile Belt and its boundaries. Special Publication Geology Society of South Africa, 10, 91-100.

De Beer, J.H. and Meyer, R. (1984). Geophysical characteristics of the Namaqua-Natal Mobile Belt and its boundaries, South Africa. Journal of Geodynamics, 1, 473-494

De Beer, J.H., van Zyl, J.S.V. and Bahneman, F.K. (1974). Plate tectonic origin for the Cape Fold Belt. Nature, 252, 675-676

De Beer, J.H, van Zijl, J.S.V. and Gough, D.I. (1982) The Southern Cape Conductive Belt (South Africa): Its composition, origin and tectonic significance. Tectonophysics, 83, 205-225.

De Wit, M.J. and Horsfield, B. (2006). Inkaba ye Africa Project Surveys Sector of Earth from Core to Space. EOS, American Geophysical Union, 87, 113-117.

Dewey, J.F., Robb, L. and van Schalkwyk, L. (2006). Did Bushmanland extentionally unroof Namaqualand? Precambrian Research, 150, 173-182.

Du Plessis, A. and Simpson, E.S.W. (1974). Magnetic Anomalies associated with the southeastern continental margin of South Africa. Marine Geophysical Researches, 2, 99-110.

Eglington, B.M. (2006). Evolution of the Namaqua-Natal Belt, southern Africa - A geochronological and isotope geochemical review. Journal of African Earth Sciences, 46, 93-111.

Eglington, B.M. and Armstrong, R.A. (2003). Geochronological and isotopic constraints on the Mesoproterozoic Namaqua-Natal Belt: evidence from deep borehole intersection in South Africa. Precambrian Research, 125, 179-189.

Evenchick C.A., Gabrielse, H. and Snyder D. (2005). Crustal structure and lithology of the northern Canadian Cordillera: alternative interpretations of SNORCLE seismic lines 2a and 2b. Canadian Journal of Earth Science, 42, 1149-1161

Fatti, J.L. and Du Toit, J.J.L. (1970). A regional reflection-seismic line in the Karoo basin near Beaufort West. Transactions of the Geological Society of South Africa, 73, 17-28

Frimmel, H.E. and Frank, W. (1998). Neoproterozoic tectono-thermal evolution of the Gariep Belt and its basement, Namibia and South Africa. Precambrian Research, 90, 1-28.

Gibson, B.S. and Levander, A.R. (1987). Imaging deep reflectors in the presence of signal-generated noise. IGCP project 474 Images of the Earth's crust and upper mantle, Geophysical Journal, 89, 1-20.

Gough, D., de Beer, J. and van Zijl, J. (1973), A magnetometer array study in southern Africa, Geophysical Journal of the Royal Astronomy Society, 34, 421-433

Green, R.W.E. and Durrheim, R.J. (1990). A seismic refraction investigation of the Namaqualand Metamorphic Complex, South Africa. Journal of Geophysical Research, 95, 19927-19932.

Groenewald, P., Grantham, G. and Watkeys, M. (1991). Geological evidence for a Proterozoic to Mesozoic link between southeastern Africa and Dronning Maud Land, Antarctica. Journal of the Geological Society of London, 148, 1115-1123.

Hälbich, I.W. (1983). A tectonogenesis of the Cape Fold Belt (CFB). Special Publication of the Geological Society of South Africa, 12, 165-175.

Hälbich, I.W. and Swart, J (1983). Structural zoning and dynamic history of the cover rocks of the Cape Fold Belt. Special Publication of the Geological Society of South Africa, 12, 75-100.

Hälbich, I.W. (Compiler) (1993). Global Geoscience Transect 9. The Cape Fold Belt - Agulhas Bank transect across Gondwana Suture, Southern Africa. American Geophysical Union Special Publication, 202, 18pp.

Hartzer, F.J., Johnson, M.R. and Eglington, B.M. (1998) The Stratigraphic Table of South Africa. Council for Geoscience Map Publication Series, Pretoria, South Africa.

Harvey, J.D., de Wit, M.J., Stankiewicz, J. and Doucoure, C.M. (2001)
Structural variations of the crust in the southwestern Cape, deducted from seismic receiver functions. South African Journal of Geology, 104, 231-242. Hoffman, P.F. (1991). Did the breakout of Laurentia turn Gondwanaland inside-out? Science, 252, 1409-1412.

Hoffman, P.F. (1999). The break-up of Rodinia, birth of Gondwana, true polar wander and the snowball Earth. Journal of African Earth Science, 28, $17-33$.

Jacobs, J. and Thomas, R.J. (1994). Oblique collision at about 1.1Ga along the southern margin of the Kaapvaal continent, south-east Africa. Geologische Rundschau, 83, 322-333.

Jacobs, J., Thomas, R. and Weber, K. (1993). Accretion and indentation tectonics at the southern margin of the Kaapvaal craton during Kibaran (Grenville) orogeny. Geology, 21, 203-206.

Johnson, M.R., Van Vuuren, C.J. Visser, J.N.J, Cole, D.I., De V Wickens, H., Christie, A.D.M and Roberts, D.L. (1997) The Foreland Karoo Basin, South Africa. In: R.C. Selley (Editor), K.J. Hsu (Series Editor), African Basins. Sedimentary Basins of the World, Elsevier Science B.V., Amsterdam, The Netherland, 3, 269-317.

Jokat, W., Boebel, T., König, M. and Meyer, U. (2003). Timing and geometry of early Gondwana breakup. Journal of Geophysical Research, 108, 2428.

Knütter, R.K.C. (1994) Geologische Kartierung in der Umgebung von Laingsburg. Diplomarbeit. Universität Bonn, Germany. 93pp.

König, M. and Jokat, W. (2006). The Mesozoic breakup of the Weddell Sea. Journal of Geophysical Research, 111, B12102, doi:10.1029/2005JB004035. Kwadiba, M.T.O.G., Wright, C., Kqaswane, E.M., Simon, R.E. and Nguuri, T.K. (2003). Pn arrivals and lateral variations of Moho geometry beneath the Kaapvaal Craton. Lithos, 71, 393-411.

Ludden, J. and Hynes, A. (2000). The Atibi-Grenville Lithoprobe transect: two billion years of crust formation and recycling in the Precambrian shield of Canada. Canadian Journal of Earth Science, 37, 459-476.

Mahanyele, P. J. Bauer, K. Franke, D. Schulze, A. Ryberg, T. De Beer, C. H. Neben, S. Schreckenberger, B. and Stettler, E. H. (2004). How far to the south does the volcanic margin of Southwest Africa extend? An initial velocity model for the ocean-continent transition in the southern Cape Basin. Poster at 64.Jahrestagung der Deutschen Geophysikalischen Gesellschaft, Berlin, Germany.

Martignole, J., Calvert, A.J., Friedman, R. and Reynolds, P (2000). Crustal evolution along a seismic section across the Grenville Province (western Quebec). Canadian Journal of Earth Science, 37, 291-306.

McCourt, S., Armstrong, R.A., Grantham, G.H. and Thomas, R.J. (2006). Geology and evolution of the Natal belt, South Africa. Journal of African Earth Sciences, 46, 71-92.

Milani, E.J. and de Wit, M.J. (2007). Correlations between the classic Paraná and Cape-Karoo sequences of South America and southern Africa and their basin infills flanking the Gondwanides: Du Toit revisited. In: R. J. Pankhurst, R. A. J. Trouw, B. Brito Neves and M. J. de Wit (editors). West Gondwana: Pre-Cenozoic Correlations Across the South Atlantic - The Ties That Bind. The Geological Society, London, Special Publication, in press. Mooney, W., Laske, G. and Masters, G (1998). Crust 5.1: a global crustal model at 5x5 degrees, Journal of Geophysical Research, 103, 727-747 and http://mahi.ucsd.edu/Gabi/rem.html.

Moores, E.M. (1991). Southwest US-East Antarctica (SWEAT) connection: A hypothesis. Geology, 19, 425-428.

Newton, A.R. (1992). Thrusting on the northern margin of the Cape Fold Belt, nears Laingsburg. In: M. J. De Wit and I.D.G. Ransome (Editors). Inversion tectonics of the Cape Fold Belt, Karoo and Karoo and Cretaceous basins of Southern Africa, Balkema, Rotterdam, Netherlands, 193-197.

Parsiegla, N., Gohl, K. and Uenzelmann-Neben, G. (2007.) Deep crustal structure of the sheared South African continental margin: first results of the Agulhas-Karoo Geoscience Transect. South African Journal of Geology, 110, 393-406

Paton, D.A., Macdonald, D.I.M. and Underhill, J.R. (2006). Applicability of thin or thick skinned structural models in a region of multiple inversion episodes; Southern Africa. Journal of Structural Geology, 28, 1933-1947.

Pitts, B.E. and Maher, M.J. (1991). Magnetic and gravity interpretation of crustal structure in the southern Cape Province of South Africa. Society of Exploration Geophysicists (SEG) Abstracts, Houston, Texas, 61, 650-653. Pitts, B.E., Maher, M.J., de Beer, J.H. and Gough, D.I. (1992). Interpretation of magnetic, gravity and magnetotelluric data across the Cape Fold Belt and Karoo Basin. In: M. J. De Wit and I.D.G. Ransome (Editors). Inversion 
tectonics of the Cape Fold Belt, Karoo and Karoo and Cretaceous basins of Southern Africa, Balkema, Rotterdam, Netherlands, 27-32.

Raith, J.G., Cornell, D.H., Frimmel, H.E. and De Beer, C.H. (2003). New insights into the gology of the Namaqua tectonic province, South Africa, from Ion Probe dating of detrital and metamorphic Zircon. Journal of Geology, 111, 347-366.

Robb, L.J., Armstrong, R.A. and Waters, D.J. (1999). The history of GranuliteFacies metamorphism and crustal growth from single Zircon U-Pb geochronology: Namaqualand, South Africa. Journal of Petrology, 40, 1747-1770.

Stankiewicz, J., Ryberg, T., Schulze, A., Lindeque, A.S., Weber, M.H. and De Wit, M.J. (2007). Initial Results from wide-angle seismic refraction lines in the Southern Cape. South African Journal of Geology, 110, 407-418.

Tankard, A.J., Jackson, M.P.A., Erikson, K.A., Hobday, D.K., Hunter, D.R. and Minter, W.E.L. (1982). Crustal evolution of Southern Africa. 3.8 billion years of earth history, Springer-Verlag, New York, United States of America, 532pp.

Thomas, R.J., Agenbacht, A.L.D., Cornell, D.H. and Moore, J.M. (1994). The Kibaran of southern Africa: Tectonic Evolution and metallogeny. Ore Geology Reviews, 9, 131-160

Torsvik, T.H. (2003). The Rodinia Jigsaw Puzzle. Science, 300, 1379-1381.

Visser, J.N.J. (1987). The Palaeogeography of part of southwestern Gondwana during the Perm-Carboniferous glaciation. Paleogeogaphy, Palaeoclimaology, Palaeoecology, 61, 205-219.

Visser, J.N.J., Loock, J.C. and Colliston, W.P. (1987). Subacqueous outwash fan and esker sandstones in the Permo-Carboniferous Dwyka Formation of
South Africa. Journal of Sedimentary Petrology, 57, 467-478.

Wamer, M. (1987). Migration - why doesn't it work for deep continental data. IGCP project 474 Images of the Earth's crust and upper mantle, Geophysical Journal, 89, 1.

Weckmann, U., Ritter, O., A. Jung., Branch, T. and de Wit, M. (2007a). Magnetotelluric measurements across the Beattie magnetic anomaly and the Southern Cape Conductive Belt, South Africa. Journal of Geophysical Research, 112, doi:10.1029/2005JB003975.

Weckmann, U., Jung, A., Branch, T. and Ritter, O. (2007b). Comparison of electrical conductivity structures and 2D magnetic modelling along two profiles crossing the Beattie Magnetic Anomaly, South Africa. South African Journal of Geology, 110, 449-464.

White, D.J., Forsyth, D.A., Asudeh, I., Carr, S.D., Wu, H., Easton, R.M. and Mereu, R.F. (2000). A seismic-based cross section of the Grenville Orogen in southern Ontario and western Quebec. Canadian Journal of Earth Science, 37, 183-192.

Winardhi, S and Mereu R.F. (1997). Crustal velocity structure of the Superior and Grenville provinces of the southeastern Canadian Shield. Canadian Journal of Earth Science, 34, 1167-1184.

Wright, C., Kgaswane, E.M., Kwadiba, M.T.O., Simon, R.E., Nguuri, T.K. and McRae-Samuel, R. (2003). South African seismicity, April 1997 to April 1999, and regional variations in the crust and uppermost mantle of the Kaapvaal Craton. Lithos, 71, 369-392.

Editorial handling: M.J. de Wit and Brian Horsfield 